
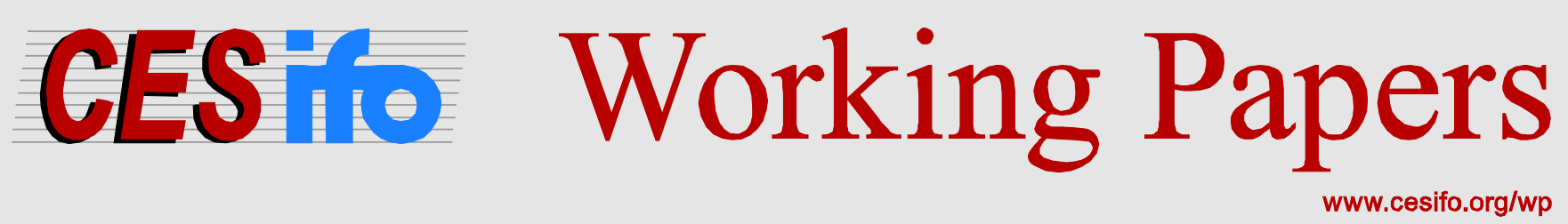

\title{
Creeping Normalcy: Fractionation of Indian Land Ownership
}

\author{
Jake Russ \\ Thomas Stratmann
}

CESIFO WORKING PAPER NO. 4607

CATEgory 2: PuBlic CHOICE

JANUARY 2014

An electronic version of the paper may be downloaded

- from the SSRN website:

- from the RePEc website:

- from the CESifo website:

wWw.SSRN.com

Www.RePEc.org

www.CESifo-group.org/wp

\section{CESifo}




\title{
Creeping Normalcy: Fractionation of Indian Land Ownership
}

\begin{abstract}
In 1992 the General Accounting Office (GAO) published a quantitative survey of Indian land ownership of twelve reservations, which was the first and still is the only survey of Indian land ownership. In our study we use 2010 data to show how ownership fractionation for these reservations has changed since the original GAO study. We find that, despite the whole of Congressional action regarding land fractionation, and the US Bureau of Indian Affairs “ (BIA's) land consolidation programs, fractionation has not only continued, but BIA's complex recordkeeping workload has nearly doubled for the twelve reservations over the eighteen year interval. The GAO estimated that BIA's annual recordkeeping costs for these twelve reservations was between $\$ 40$ and $\$ 50$ million. With the addition of over a million new ownership records, due to fractionation, we estimate yearly recordkeeping costs have increased to \$246 million in 2010.
\end{abstract}

JEL-Code: O100, Y100.

Keywords: Indian land ownership, ownership fractionation, Indian reservations.

Jake Russ

Department of Economics

George Mason University

4400 University Drive

USA - 22030 Fairfax VA

jruss2@gmu.edu
Thomas Stratmann

Department of Economics

George Mason University

4400 University Drive

USA - 22030 Fairfax VA

tstratma@gmu.edu

December 2013

We thank the Bureau of Indian Affairs, the Indian Land Working Group, the Indian Land Tenure Foundation, tribal governments, and tribes for providing data and information used in this study. 


\section{Contents}

\begin{tabular}{lr}
\hline Highlights & 3
\end{tabular}

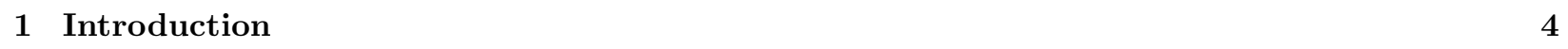

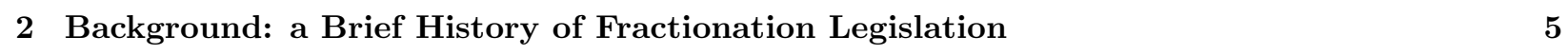

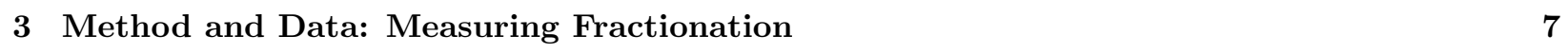

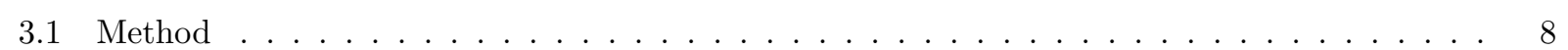

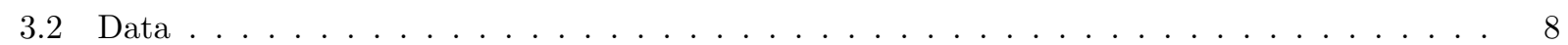

\begin{tabular}{|lrr}
\hline & Fractionation Revisited & 8
\end{tabular}

4.1 Tribal Membership . . . . . . . . . . . . . . . . . . . . . . . . . . . . . . . . . 8

4.2 Tracts and Acreage Managed by BIA $\ldots \ldots \ldots \ldots \ldots \ldots \ldots$

4.3 BIA-Managed Tracts for Surface and Subsurface Use . . . . . . . . . . . . . . . . 10

$4.4 \quad$ Ownership Profile of BIA-Managed Tracts $\ldots \ldots \ldots \ldots \ldots$

4.5 Ownership Mix on Tracts with Fractionated Ownership $\ldots \ldots \ldots \ldots$. . . . . . . . . . 12

4.6 Tracts with Fractionated Ownership, by Number of Indian Owners per Tract . . . . . . . . . 14

4.7 Largest Number of Owners on a Single Tract, by Reservation . . . . . . . . . . . . . . . 14

$4.8 \quad$ Largest Number of Owners on a Single Tract, by Reservation . . . . . . . . . . . . . . . 15

4.9 Individual Indian Ownership in Multiple Tracts $\ldots \ldots \ldots \ldots \ldots$

4.10 Indian with the Most Ownership Interests, by Reservation . . . . . . . . . . . . . . . . . 16

4.11 Individual Indians' Consolidated Ownership Interests, by Size of Interest . . . . . . . . . . . 17

4.12 Smallest Indian Individual Ownership Interest, by Reservation ～. . . . . . . . . . . . . 18

4.13 Number of Ownership Records BIA Maintains . . . . . . . . . . . . . . . . . . . . . . . . . 19

4.14 Ownership Records, by Owner Type ． . . . . . . . . . . . . . . . . . . . . . . . . 20

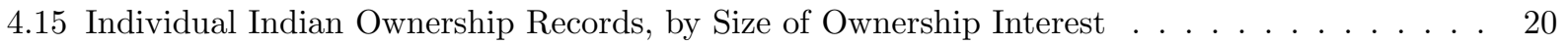

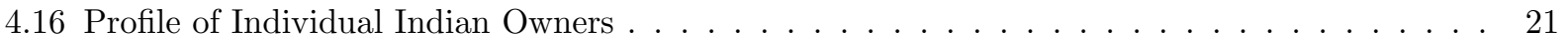

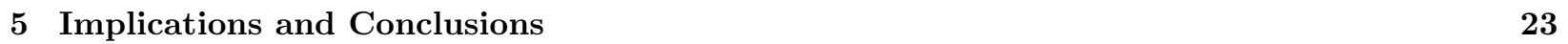

\begin{tabular}{ll}
\hline Technical Appendix & 25
\end{tabular}

\begin{tabular}{lr}
\hline References & 26
\end{tabular} 


\section{Highlights}

1. Fractionation of ownership on Indian reservations-that is, the total number of undivided interests of Indian owned parcels of land-roughly doubled on twelve reservations between 1992 and 2010. We find this result regardless as to whether we compute fractionation by using consolidated or non-consolidated ownership measures. Consolidation refers to the grouping of several ownership interests into a single ownership record, when individual Indians own more than one ownership stake in a given land parcel. During this period, undivided ownership interests increased by a total of 1,051,399 records, and consolidated ownership interests increased by 623,322 records (Tables 11 and 13, p. 19-20). The average rate of fractionation also increased by 44,500 new interests per year, up from an average of 35,000 per year between 1983 to 1992 (p. 23).

2. The number of fractionated tracts on the twelve reservations sample increased from 36,134 in 1992 to 43,770 by 2010 , amounting to a 21.1 percent increase. Further, the frequency distribution of owners per tract shifted to the right. For example, between 1992 and 2010 the number of tracts with between three and ten owners remained roughly constant in absolute numbers, but declined as a proportion of the total number of tracts (13,553 in 1992 and 13,857 in 2010). All five ownership categories above ten owners increased their proportion of the total from 1992 to 2010 (Table 6, p. 14). Most dramatically, the number of tracts with 300 or more owners increased by over 1000 percent.

3. From the perspective of an individual Indian, the number of Indians having an ownership interest in more than 50 tracts more than doubled. In the twelve reservations sample in 1992 there were 1,320 individual Indians with ownership interests in over 50 separate tracts. By 2010 that figure increased to 4,499 (Table 9, p. 17).

4. As of 2010, with over 1,000 total owners, the Standing Rock reservation has the tract with the largest number of owners among the reservations studied in this paper. Seven of the twelve reservations contain a tract with more than 500 owners (Table 8, p.16).

5. Tribes own sole possession of about one-third more tracts than in 1992, and the total number of tribal ownership interests increased three fold. Some of these increases are due to an explicit focus, by tribes and the Bureau of Indian Affairs (BIA), of acquiring small ownership interests, defined as less than a two percent ownership interest. These increases were achieved through private tribal purchases, government purchases by BIA's Indian Land Consolidation Program (ILCP), and the escheatment provision included as part of the 1983 Indian Land Consolidation Act (Tables 4 and 14, p. 12 and 21).

6. Section 207 of the Indian Land Consolidation Act (ILCA) provided that ownership interests of less than two percent would not be further inherited through the probate of an Indian owner's estate. Instead, these two percent interests would escheat to the tribe upon the death of a member Indian without a will. Section 207 was ruled unconstitutional by the Supreme Court in Hodel v. Irving (1987) and an amended version of Section 207 was also ruled unconstitutional in Babbitt v. Youpee (1997). Both rulings were for violations of the Takings Clause of the Fifth Amendment. However, since Section 207 was law between 1983 and 1997, 55,000 ownership interests were escheated to tribes. We estimate that Section 207 accounts for up to 8.6 percent of the increase in tribal ownership interests between 1992 and 2010. We further estimate that Section 207 reduced the number of small ownership interests (less than two percent) by 4.8 percent (p. 24).

7. For BIA annual recordkeeping costs, at only these twelve reservations, we estimate a fivefold increase over the last 18 years, from between $\$ 40-50$ million per year to $\$ 246$ million per year in 2010 . We document that across all federal Indian reservations in the U.S., the BIA maintains 4.6 million ownership records. This results in an annual recordkeeping cost of more than half a billion dollars. 


\section{Introduction}

Why do Indian reservations remain some of the poorest regions of the United States? One source of economic difficulty faced by Indian landowners today is land fractionation. Over the last 125 years, the number of Indians who share ownership in tracts of reservation land has been growing rapidly. Ownership in Indian land is continuing to separate into smaller and smaller interests due to an interaction between federal Indian policy and the cultural norms of Indian tribes.

The General Allotment Act of 1887 assigned ownership rights of land tracts to Indians, while also retaining those land titles in a managed trust by the Bureau of Indian Affairs (BIA). The tracts of land marked with this trust designation, carry with them restrictions regarding the alienation of the land ownership claim. For many years, Indians were barred from selling, gifting, or leasing any of these lands without approval from the Secretary of the Interior. The interaction of these restrictions with Indian tribes whose "thinking included no concept of individually-owned real property such as that brought by the original white settlers from western Europe" (Gilbert and Taylor, 1966, p. 111) generated the heirship problem known as fractionation.

Prior to allotment, reservation land was communally controlled by the tribe. Tribes that were relatively sedentary assigned use rights to individual families, but these rights were informal and subject to revision by the tribe, if necessary. The more nomadic tribes-who subsisted by hunting and gathering-did not assign use rights 1 The use of informal property right mechanisms meant Indian inheritance systems did not use formal wills. But after allotment, when an Indian land owner died without a will, federal regulations dictated that inherited property was to be distributed according to state probate law: usually equally among the surviving heirs. With the passing of just a few generations, the sheer number of owners on Indian land increased dramatically. And as the number of owners to a tract of land increased, so did the likelihood of negative economic consequences, because trust restrictions prevented resources from moving to their highest value use.

The major challenge confronting scholars who wish to assess potential negative effects of fractionation, is that a systematic accounting of Indian land fractionation does not exist with possibly one exception ${ }^{2}$ This exception is a 1992 General Accounting Office (GAO) study, which reports statistical summaries of ownership interests, but for only twelve of the several hundred land areas that are federally recognized as Indian Reservations. The GAO used a data set from BIA to produce, "Profile of Land Ownership at 12 Reservations," which detailed the state of fractionation in $19923^{3}$

The economics and law literatures (see, for example, for the economics literature, McChesney 1990 Anderson and Lueck 1992; Anderson and Parker 2006; Akee 2009; and for the law literature, Gilbert and Taylor 1966; Lindo 1997; Heller 1998; Guzman 2000; Bobroff 2001; Shoemaker| 2003; McCulley |2005) have identified Indian land fractionation as a factor which hinders economic development, but these works are forced to argue that case by way of anecdotal evidence, since statistics about the growth of fractionation simply did not exist, until now. This study contributes to those literatures by first providing an update to the original GAO study, showing how fractionation has changed for these reservations since 1992, using BIA land ownership data from 2010. After measuring the growth of fractionation between 1992 and 2010, we can then evaluate Congressional and BIA efforts to eliminate fractionation. We find that, despite the whole of Congressional action regarding land fractionation, and BIA's land consolidation programs, fractionation has not only continued on its growth path, but the number of ownership records BIA maintains have nearly

1 "Toward a Theory of Property Rights" (Demsetz, 1967) uses this example explicitly.

2 There is a tension between making ownership data available for study by researchers and for protecting "personally identifiable information." The latter contributes to the lack of information about fractionation on Indian reservations. The Bureau of Indian Affairs maintains their master database, Trust Asset and Accounting Management system (TAAMS), but this data is considered "trust property" and belongs to the Federal Indian Trust for the Indian beneficiaries. Information about land records, natural resources, or funds held by the federal government, contained within TAAMS are all not subject to a Freedom of Information Act (FOIA) request. This is similar to the data from the Social Security Administration. Here, personally identifiable information are also not subject to FOIA requests.

${ }^{3}$ The twelve reservations are Blackfeet, Cheyenne River, Colville, Crow, Fort Berthold, Fort Peck, Pine Ridge, Rosebud, Standing Rock, Turtle Mountain, Wind River, and Yakima. The GAO focused their study on these reservations because they were "cited as examples of extensive land ownership fractionation in 1984 hearings on amendments to the 1983 [Indian Land Consolidation Act]" (United States. General Accounting Office and United States. Congress. Senate. Select Committee on Indian Affairs 1992 , p. 1). 
doubled over that eighteen year interval.

For just these twelve reservations in 1992 the total number of ownership records were 1,059,592, and we find that by 2010 , that figure almost doubled to $2,110,991$. It is also more common in 2010 , than in was in 1992, for an individual Indian to own several interests in the same tract of land, due to inheriting interests at different times. Thus, an alternative way of measuring fractionation is to consolidate ownership records by owner, and then to count how many consolidated ownership interests are being managed by BIA. We find that in 1992 these consolidated ownership interests totaled 704,562, and by 2010 that figure rose by 88 percent, to $1,327,884{ }^{4}$ Further, we estimate that the populations on these twelve reservations grew by 46.1 percent during this period, demonstrating that, even after consolidating ownership interests, fractionation cannot be explained solely by population growth.

Our study proceeds as follows: In Section 2, we briefly discuss the history of fractionation, with a focus on Congressional action regarding Indian land fractionation. In Section 3, we discuss our data set and the accounting method for our analysis. In Section 4, we present the results of our investigation into the state of fractionation. In Section 5, we examine three main implications of our results, use them to evaluate Congress' fractionation policies, and present conclusions.

\section{Background: a Brief History of Fractionation Legislation}

Legislation that has resulted in fractionation dates back to the 19th century. While there were land allotments prior to 1887, the General Allotment Act of 1887, or "Dawes Act," is considered the beginning for land fractionation (Swimmer, 2004). This legislation established the systematic land allotment process and federal trust relationship for Indian reservations in the United States.

The original allottees were assigned ownership of land tracts, sized either as 80 acres for individual farmland, 160 acres for family farms, or up to 320 acres for grazing land. Due to concerns over the competency of these Indian owners, however, the legal titles were held in trust by the federal government, while the Indian owners received only beneficial title (Guzman, 2000). The trust period was originally intended to last only twenty-five years, and during this period, "all conveyances (e.g., sale, gift, devise, exchange, lease, or mortgage) were prohibited and thus void unless made with the approval of the Secretary of the Interior" Guzman, 2000, p. 604). The stated intent of the twenty-five year trust relationship was to allow Indian landowners-who used a "common property" approach to land-to adjust to formal real estate procedures and notions of individual private property, while relying "upon the government of the United States to protect their property and personal interests. [from] the dubious attempts of self-seeking traffickers in Indian ignorance and credulity" (Meriam et al., 1928, p. 780).

The trust relationship between the tribes and the U.S. federal government was extended as part of the Indian Reorganization Act (IRA) of 1934, and remains in place today. Acres not allotted as part of the Dawes Act were labeled "surplus" and made available for sale to non-Indians. Deputy Solicitor Edward Cohen reported in his 1998 testimony to Congress that the direct effect of the Dawes Act was that Native Americans lost over 100 million "surplus" acres, roughly two-thirds of the reservation trust land base between the passing of the Dawes Act in 1887 and the IRA which ended allotment in 1934 (Cohen, 1998).

A further consequence of the Dawes Act was to create the "heirship problem" known as fractionation (Cohen, 1998). Because Indian tribes manage inheritances through informal tribal systems, the writing of formal wills is not a part of traditional Indian cultures. But since BIA manages trust acres, it is charged with probating the estates of landowners. Many of the original allottees, and their descendants, died without a will (intestate). The Dawes Act was silent on this particular issue, which left the inheritance of allotted property to be decided-in the same manner as other classes of private property-by state probate rules. The U.S. Department of Interior (DOI) would administer the probate cases, but DOI would settle each case as the individual state rules dictated and distribute the allotments, usually equally, among the remaining family members (Nordwall, 2003). As the theoretical example in Figure 1 shows, this process adds ownership

\footnotetext{
4 According to 2004 testimony from Special Trustee Ross Swimmer, BIA attempted to replicate the 1992 GAO report in 2002. Trustee Swimmer reported then that BIA's results suggested the fractionation problem had increased by over 40 percent.
} 
interests exponentially, and the figure also shows that it only takes a few generations to pass before a tract of land acquires a vast number of owners.

Figure 1

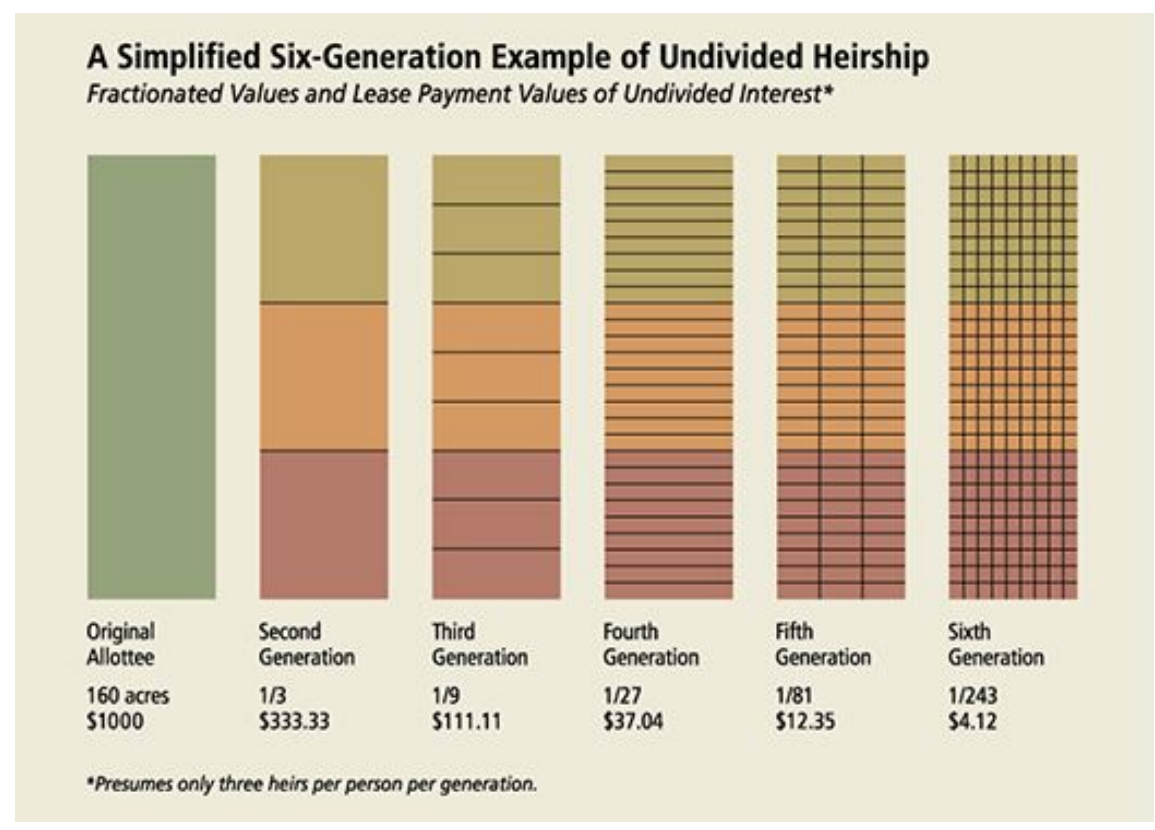

Source: Indian Land Tenure Foundation

As early as the 1920s, scholars suggested that the above described land allotment had negative economic consequences for the Indian country. Allotment meant that large swaths of tribal, communally held lands were broken into smaller parcels, and checkerboarded, which reduced the tribes' ability to use the land effectively. As Carlson (1981) shows, Indian farming activity actually decreased as a result of allotment by the Dawes Act. Fractionation further reduces the likelihood of successful farming by subdividing ownership of these already inadequately sized land parcels into many hundreds of small claims per tract.

An example of this scholarship is a 1928 Brookings Institute report, "The Problem of Indian Administration," known also as the 'Meriam Report.' This study criticized the Dawes Act and formed the basis for the IRA in 1934, Congress' first attempt to address fractionation (Swimmer, 2004, p. 3). However, according to DOI Special Trustee Ross O. Swimmer, the IRA failed to meaningfully address fractionation, because many of the land reform provisions were removed due to tribal opposition (Swimmer, 2004, p. 3). Thus, fractionation continued as Congress' next attempt to address it with major federal legislation was not passed until 1983.

In 1983 Congress passed the Indian Land Consolidation Act (ILCA). Although the period between these major Congressional actions is significant, it was not for a lack of federal activity related to fractionation. For example, Swimmer (2004) cites a 1938 Department of the Interior meeting which attempted to formulate a solution to the issue. Di Giulio (1994) reports that bills purporting to address fractionation were introduced in Congress every year from 1950 to 1960, but none were passed. Congress initiated a survey in 1958, which was mailed to tribal members, in order to quantify the extent of the "heirship problem" (Di Giulio, 1994). Another example of ongoing activity regarding the fractionation issue is the 1961 creation of a Task Force on Indian Affairs. This Task Force "recommended the Secretary of the Interior eliminate fractionation by granting the Secretary the authority to transfer fractional interests from tribal members to the tribe, in exchange for just compensation" (Di Giulio 1994, p. 48). Additionally, Congress created the American Indian Policy Review Commission in 1977. This Commission was designated as the Senate Committee on Indian Affairs in 1984.

The major provision in ILCA attempting to slow the fractionation of ownership interests was the escheat 
provision in Section 207. Section 207 established the "two percent rule," where interests of two percent or less would escheat to the tribe upon the death of a member who did not have a will. The intent of this provision was that small interests would cease splitting into even smaller interests and Indians would reap the benefits of consolidation, if only at the tribe level. Section 207 was challenged in court, which led to Congressional amendments to ILCA in 1984. Ultimately, in 1987, the Supreme Court ruled Section 207 unconstitutional in Hodel v. Irving, because Section 207 amounted to "taking of property without just compensation" (481 U.S. 704, 1987). However, the Court did not rule on the 1984 amendments, leaving open the possibility of further escheatment consolidations (Swimmer, 2004, p. 5). The amended escheatment considerations remained until 1997, when the Court also ruled the amendments to Section 207 as a violation of the Takings Clause of the Fifth Amendment in Babbitt v. Youpee .

A second round of amendments was made to ILCA in 2000, placing restrictions on which heirs could receive property through the probate system. In his 2004 testimony, DOI Trustee Ross Swimmer states that the heirship restrictions have not been successful, due to the costs of carrying them out. However, he also noted that BIA was running a successful land consolidation program since 1999. The Indian Land Consolidation Program (ILCP), established as part of the 2000 amendment process to ILCA, purchased 78,321 fractional interests from 1999 to March 2004, covering about 49,155 acres (Swimmer, 2004, p. 5). The total funding for ILCP, through 2003, was $\$ 37.7$ million (Chickasaw Nation Industries, 2012). This works out to an average of $\$ 481$ per fractional interest, or $\$ 767$ per acre.

In 2004, Congress passed the American Indian Probate Reform Act (AIPRA). This act created a uniform federal probate code, replacing the vast network of state by state probate court procedures and expanded BIA's land consolidation program. AIPRA made ILCP a permanent program and authorized as much as $\$ 605$ million to be spent from 2005 to 2009 , but only $\$ 115.5$ million of that total would actually be funded to ILCP (Chickasaw Nation Industries, 2012). The budget for ILCP was moved from the Office of the Special Trustee (OST) to BIA in 2009, but only an additional $\$ 3$ million was funded to ILCP after 2009 (Chickasaw Nation Industries, 2012). Today, the program maintains a much reduced operating staff and scale using only funds re-invested from income derived from the previously purchased interests.

The latest significant court case was Cobell v. Salazar initiated in 1996 by Mrs. Elouise Cobell, a member of the Blackfeet tribe. This class action suit against the federal government alleged that BIA mismanaged income, and thus failed to distribute income generated from reservation lands held in trust by BIA. The case centered on BIA's inability to provide tribes with an accurate historical accounting of ownership records and money distributed through the Individual Indian Money (IIM) accounts. The case was brought to a conclusion in 2009 when the Obama Administration announced a $\$ 3.4$ billion dollar settlement (Reis, 2009). This case suggests that fractionation created a complex maze of ownership records, which contributed to BIA's failure to fulfill its recordkeeping mandate.

\section{Method and Data: Measuring Fractionation}

In 1992 Congress commissioned GAO to systematically account for land fractionation on Indian reservations. To date, "Profile of Land Ownership at 12 Reservations" is the only accounting of ownership interests in Indian reservation land. Even though it only covers twelve reservations, by giving a snapshot of fractionation in 1992 this study is a benchmark we use to measure the degree to which fractionation on these reservations changed between 1992 and 2010, the latter being the date of our data. With this comparison we assess the change of fractionation over time, and can evaluate the effectiveness of Congressional and BIA efforts to remedy fractionation.

The twelve reservations selected for analysis in the original GAO study were not random. They were selected because these reservations were locations already known to BIA and Congress as examples with the highest degrees of fractionation, from them being cited in the 1984 amendment process to ILCA (United) States. General Accounting Office and United States. Congress. Senate. Select Committee on Indian Affairs, 1992 p. 1). Given that we analyze these reservations, we at the same time also focus on those reservations that Congress targeted with legislation to mitigate land fractionation. 


\subsection{Method}

The only surviving documentation for the 1992 GAO study is the document itself. None of the underlying data or statistical programs used to analyze the data is available. Lacking the GAO's underlying documentation, we have to infer some calculations. In this process we noticed the GAO's somewhat unique accounting methods. For example, when calculating acreages, the GAO study reports figures that aggregate land areas from surface and subsurface tracts. Since many of these areas overlap, this produces acreages larger than the actual surface area of the reservation. In order to maintain consistency between our study and GAO's we report acreages in this "combined" format, in addition to reporting actual surface acres under BIA's trust management. We followed the GAO method because maintaining consistency between the GAO study and our analysis will allow us to obtain an accurate measurement of the change in fractionation.

At the time of GAO's publication, the GAO was limited by the data contained in BIA's legacy Land Record Information System (LRIS). Our report uses a data extract from the Trust Asset and Accounting Management System (TAAMS), a new data management system adopted by BIA in January 2006. Thus, our analysis benefits from the database improvements that TAAMS provides over the LRIS database.

\subsection{Data}

BIA provides us with a statistical extract of land ownership data from the TAAMS database. The BIA removed all personal and trust information pertaining to specific individuals. However, the data does include a unique statistical data element (a system reference number) that allows ownership interests to be grouped at the owner level. Our data set covers all of the BIA designated land areas as of April 2010.

The data set contains information on ownership percentage interests, tract acres, tract and land area codes, resource codes (for surface and subsurface designations), owner type (Indian, tribe, non-Indians, government agency), and tribal group codes. These variables were sufficient information to reproduce 15 of the 17 tables reported in the 1992 GAO study. For one of the remaining two tables, that is, tribal membership counts, we obtained estimates directly from tribal enrollment offices.

\section{Fractionation Revisited}

As of April 2010, BIA is managing over 220,000 tracts of land which amount to approximately 56 million surface acres of reservation land. These 220,000 tracts additionally include another 12 million acres which are defined as subsurface tracts. About half of the 220,000 tracts are owned by two or more individuals or entities. In acreage terms, these fractionated tracts represent roughly 8 million surface acres and 5.8 million subsurface acres, amounting to 14.3 percent of surface acres and 48.3 percent of subsurface acres.

The twelve reservations comprise a subset of all reservations, accounting for over 98,000 tracts and nearly 13 million surface acres and over 6 million subsurface acres, or in percentage terms relative to all reservations, 23.2 and 50 percent, respectively. Table 2, discussed below, provides a breakdown of this acreage by reservation.

\subsection{Tribal Membership}

We obtained tribal enrollment figures by calling tribal enrollment offices for the twelve reservations. Statistics for enrolled tribal membership as of 2010 were not available for the bulk of the twelve reservations, so Table 1 lists estimates for 2013 when those data were available. In our phone survey, three tribes (Arapahoe, Blackfeet, and Yakama) could not provide a breakdown of their on-reservation and off-reservation membership. However, we obtained estimates of total membership for all twelve reservations. A comparison of Table 1.1 from the GAO study and our Table 1 shows that total tribal membership on these twelve reservations increased from 145,648 to 212,794; a 46.1 percent increase over the twenty-one year period. 
We find that in 2013, there is an increased likelihood that an enrolled tribal member lives on the reservation. Specifically, when we omit four tribes from the 1992 data, namely Blackfeet, Yakama, and both Arapahoe and Shoshone since they were reported jointly for Wind River by GAO, the membership percentage split was 48/52 between on-reservation and off-reservation members, respectively. Omitting the same four tribes in 2013 reveals that the residence of tribal members for the remaining eleven tribes is now split between almost 58 percent for on-reservation members and 42 percent for off-reservation members.

Table 1: Tribal Membership

\begin{tabular}{|c|c|c|c|c|c|}
\hline \multirow[b]{2}{*}{ Reservation } & \multirow[b]{2}{*}{ Tribal affiliation } & \multirow[b]{2}{*}{ State } & \multicolumn{3}{|c|}{ Enrolled tribal members } \\
\hline & & & $\begin{array}{l}\text { Residing on } \\
\text { reservation }\end{array}$ & $\begin{array}{l}\text { Residing off } \\
\text { reservation }\end{array}$ & $\begin{array}{l}\text { Total tribal } \\
\text { membership }\end{array}$ \\
\hline Blackfeet & Blackfeet & Montana & & & 17,138 \\
\hline Cheyenne River & Cheyenne River Sioux & South Dakota & 8,000 & 10,000 & 18,000 \\
\hline Colville & Colville & Washington & 4,700 & 4,700 & 9,400 \\
\hline Crow & Crow & Montana & 9,000 & 3,000 & 12,000 \\
\hline Fort Berthold & Arikara, Mandan, Hidatsa & North Dakota & 6,610 & 6,609 & 13,219 \\
\hline Fort Peck & Assinibone, Sioux & Montana & 6,400 & 6,600 & 13,000 \\
\hline Pine Ridge & Oglala & South Dakota & 30,000 & 15,364 & 45,364 \\
\hline Rosebud & Rosebud Sioux & South Dakota & 12,763 & 2,675 & 15,438 \\
\hline Standing Rock & Standing Rock Sioux & North Dakota, South Dakota & 10,133 & 5,867 & 16,000 \\
\hline Turtle Mountain & Chippewa & North Dakota & 12,906 & 18,751 & 31,657 \\
\hline Wind River & Shoshone & Wyoming & 2,071 & 2,107 & 4,178 \\
\hline Wind River & Arapahoe & Wyoming & & & 7,400 \\
\hline Yakama & Yakama & Washington & & & 10,000 \\
\hline Total & & & 102,583 & 75,673 & 212,794 \\
\hline GAO 1992 & & & 73,920 & 71,728 & 145,648 \\
\hline
\end{tabular}

Note: this table corresponds to Table 1.1 in the 1992 GAO report.

\subsection{Tracts and Acreage Managed by BIA}

Our Table 2, which corresponds to Table 1.2 of the GAO report, gives a summary of the number of tracts and acreage managed by BIA for the twelve reservations. Table 2 lists both a combined acreage total for surface and subsurface tracts, maintaining consistency with GAO, and also the surface area only acreages $5^{5}$

The total tract acreage figure from Table 2 appears to show that the twelve reservations have grown in size. GAO reported that total tract acreage was 16.5 million acres in 1992. The same combined acreage method calculates 19.2 million acres in 2010. The actual surface area for these twelve reservations is 12.8 million acres.

While we cannot rule out minor changes to the trust status of various tracts on these reservations, BIA's accounting methods are primarily responsible for GAO's inflated acreage total. This is because when a single owner owns the surface and subsurface rights to a tract of land, BIA records the ownership interest (and tract) with a single entry. If the surface and subsurface rights are split between two or more parties, then BIA lists surface and subsurface rights as separate tracts. As Indian land ownership interests have continued to fractionate, the land records in the TAAMS system increase with respect to not only the number of owners, but also with respect to separate listings for surface and subsurface rights. Thus, due to BIA's accounting rules, the number of "tracts" maintained by BIA has also increased, without actually adding tract acreage to these reservations since many of these areas overlap.

We come to this determination because in Table 1.2 of their report, the GAO provides an acreage figure for every single reservation which is greater than the actual surface area for that reservation. This leads us to conclude that GAO aggregated both the surface and subsurface tracts together when reporting the number of tracts and acreages. To maintain comparability with their study, we report both the "combined" acreage total and a surface area-only calculation.

\footnotetext{
${ }^{5}$ The surface area only acreages were compared against surface area figures reported on the BIA's own website. The totals listed therein were within 1 or 2 percent of the surface areas listed in Table 2.
} 
As for the size composition of these tracts, in 1992, the tracts below 40 acres, tracts from 40 to 159 acres, and tracts 160 acres or more, made up 15, 35, and 50 percent of the total number of tracts, respectively. Even with the additional tracts now being recorded in TAAMS, the breakdown of tract size is roughly the same in 2010, 16.3, 35.6, and 48 percent. The average tract acreage reduced to 194 acres in 2010 from 199 acres in 1992, amounting to a 2.7 percent reduction.

Table 2: Tracts and Acreage Managed by BIA

\begin{tabular}{|c|c|c|c|c|c|c|c|c|c|}
\hline \multirow[b]{2}{*}{ Reservation } & \multirow[b]{2}{*}{$\begin{array}{r}\text { Surface } \\
\text { acreage } \\
\text { only }\end{array}$} & \multirow[b]{2}{*}{$\begin{array}{r}\text { Total } \\
\text { tract } \\
\text { acreage }\end{array}$} & \multirow[b]{2}{*}{$\begin{array}{l}\text { No. of } \\
\text { tracts }\end{array}$} & \multicolumn{3}{|c|}{ Number of tracts } & \multicolumn{2}{|c|}{ Acreage of tracts } & \multirow[b]{2}{*}{$\begin{array}{r}\text { Average } \\
\text { tract } \\
\text { acreage }\end{array}$} \\
\hline & & & & $\begin{array}{r}\text { Less than } \\
40 \text { acres }\end{array}$ & $\begin{array}{r}40-159 \\
\text { acres }\end{array}$ & $\begin{array}{r}160 \text { or } \\
\text { more acres }\end{array}$ & $\begin{array}{r}\text { Smallest } \\
\text { tract }\end{array}$ & $\begin{array}{r}\text { Largest } \\
\text { tract }\end{array}$ & \\
\hline Blackfeet & 973,708 & $1,966,346$ & 11,661 & 1,058 & 6,442 & 4,161 & 0.000 & $8,253.1$ & 169 \\
\hline Cheyenne River & $1,446,258$ & $2,212,612$ & 12,206 & 833 & 3,611 & 7,762 & 0.001 & $5,307.5$ & 181 \\
\hline Colville & $1,125,309$ & $1,293,598$ & 6,276 & 1,879 & 2,094 & 2,303 & 0.009 & $19,406.3$ & 206 \\
\hline Crow & $1,464,808$ & $2,968,232$ & 9,877 & 1,264 & 3,602 & 5,011 & 0.000 & $23,096.6$ & 301 \\
\hline Fort Berthold & 425,294 & $1,228,963$ & 9,516 & 1,222 & 4,450 & 3,844 & 0.010 & 827.5 & 129 \\
\hline Fort Peck & 910,582 & $1,455,037$ & 7,412 & 1,334 & 2,597 & 3,481 & 0.001 & $2,994.4$ & 196 \\
\hline Pine Ridge & $1,731,852$ & $2,204,087$ & 11,835 & 1,055 & 3,161 & 7,619 & 0.100 & $2,556.0$ & 186 \\
\hline Rosebud & 905,455 & $1,196,870$ & 6,825 & 293 & 1,346 & 5,186 & 0.001 & $1,729.5$ & 175 \\
\hline Standing Rock & 851,424 & $1,302,498$ & 9,940 & 3,293 & 2,107 & 4,540 & 0.010 & $2,130.0$ & 131 \\
\hline Turtle Mountain & 34,546 & 49,753 & 1,272 & 822 & 396 & 54 & 0.145 & 396.8 & 39 \\
\hline Wind River & $1,815,521$ & $2,208,873$ & 5,164 & 1,584 & 2,537 & 1,043 & 0.107 & $129,836.6$ & 428 \\
\hline Yakama & $1,129,574$ & $1,146,784$ & 6,285 & 1,417 & 2,659 & 2,209 & 0.060 & $2,802.6$ & 182 \\
\hline Total & $12,814,331$ & $19,233,653$ & 98,269 & 16,054 & 35,002 & 47,213 & & & 194 \\
\hline GAO 1992 & & $16,517,553$ & 82,978 & 12,230 & 29,007 & 41,741 & & & 199 \\
\hline
\end{tabular}

Note: this table corresponds to Table 1.2 in the 1992 GAO report.

\subsection{BIA-Managed Tracts for Surface and Subsurface Use}

Our Table 3 corresponds to table 1.3 of the original GAO report. It reports the breakdown between surface tracts, subsurface tracts, and tracts that maintain the union of both surface and subsurface rights. Table 3 provides evidence that the increased number of tracts in TAAMS is the result of single ownership interests splitting into surface and subsurface parts, because of fractionation.

As with Table 2 above, when surface and subsurface rights are owned in unity by a single individual Indian or tribe, those ownership interests are maintained with one record and the resource type is listed as "Both." When ownership rights of a plot of land are split among multiple parties, BIA maintains separate tract records for the surface and subsurface rights. The results of increased fractionation can be seen in Table 3. The number of tracts listed as "Both" fell by 7,234, and the number of surface and subsurface tracts increased by 22,543. On net, this represents an increase of 15,309 for total tracts managed. These totals do not exactly offset for several reasons. First, some tracts may have changed trust status. And second, in the TAAMS data there are five different classifications of subsurface rights, which may be listed independently ${ }^{6}$ So when a "Both surface and subsurface" tract separates, it might be broken into two or more tract records.

Figure 2 provides a visual look at the data in Table 3 and allows for a comparison between 1992 and 2010 for each reservation.

\subsection{Ownership Profile of BIA-Managed Tracts}

In Table 4, corresponding to the 1992 GAO Table 2.1, we summarize tract ownership into two groups, those tracts that are owned by a single entity and those whose ownership is split between multiple parties. Within the single entity group, we distinguish by whether the tract is owned by an individual Indian, a tribe, or 'others', where the classification of 'others' combines the ownership interests of non-Indian individuals, corporations, and federal government agencies. Within the multiple owners group, we distinguish these tracts

\footnotetext{
${ }^{6}$ These classifications are: all minerals (except oil and gas), coal, minerals only, all minerals (except coal), sand and gravel.
} 
Table 3: BIA-Managed Tracts for Surface and Subsurface Use

\begin{tabular}{lrrrr}
\hline \multicolumn{4}{c}{ Tracts } \\
\hline Reservation & $\begin{array}{r}\text { Surface } \\
\text { only }\end{array}$ & $\begin{array}{r}\text { Subsurface } \\
\text { only }\end{array}$ & $\begin{array}{r}\text { Both surface and } \\
\text { subsurface }\end{array}$ & $\begin{array}{r}\text { Total tracts } \\
\text { managed }\end{array}$ \\
\hline Blackfeet & 5,104 & 5,660 & 897 & 11,661 \\
Cheyenne River & 4,002 & 4,465 & 3,739 & 12,206 \\
Colville & 4,562 & 1,528 & 186 & 6,276 \\
Crow & 4,412 & 4,113 & 1,352 & 9,877 \\
Fort Berthold & 2,939 & 5,722 & 854 & 9,515 \\
Fort Peck & 2,236 & 2,750 & 2,426 & 7,412 \\
Pine Ridge & 2,087 & 2,459 & 7,289 & 11,835 \\
Rosebud & 1,152 & 1,576 & 4,097 & 6,825 \\
Standing Rock & 2,051 & 4,371 & 3,518 & 9,940 \\
Turtle Mountain & 404 & 312 & 556 & 1,272 \\
Wind River & 1,783 & 1,787 & 1,594 & 5,164 \\
Yakama & 260 & 308 & 5,717 & 6,285 \\
Total & 30,992 & 35,051 & 32,225 & 98,268 \\
GAO 1992 & 19,106 & 24,394 & 39,459 & 82,959 \\
\hline
\end{tabular}

Note: this table corresponds to Table 1.3 in the 1992 GAO report.

Figure 2

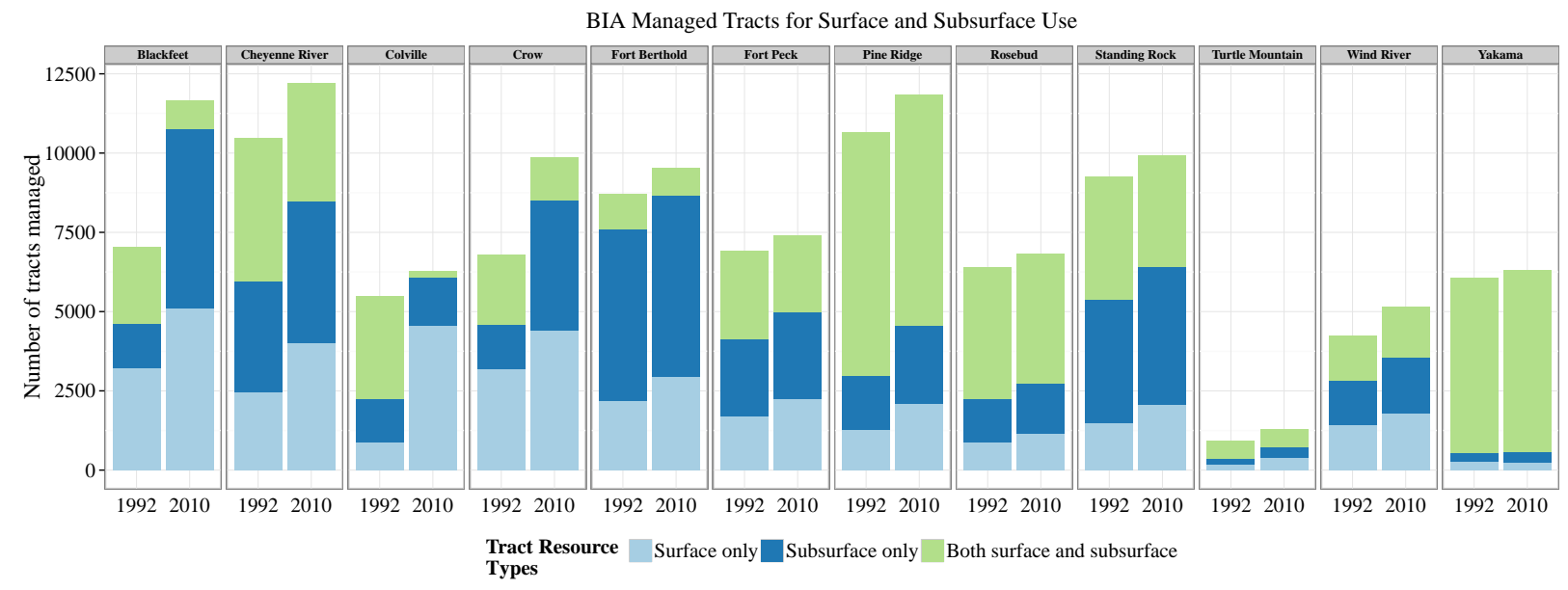


into those that have at least one individual Indian owner and those with no individual Indian owners. Tracts with multiple owners may include any combination of the aforementioned ownership classes in the 'other' category. Table 4 shows that the ownership profile of reservations has experienced two changes: tribes own many more tracts in 2010 than they did in 1992, but fractionation has also increased the number of tracts with multiple owners by over 21 percent.

Indian tribes have increased the number of tracts for which they have sole ownership by nearly a third, from 29,134 in 1992 to 38,338 in 2010. This finding is most likely due to the combination of the escheat provision in ILCA (1983) and the consolidation programs being run by BIA and the tribes independently. In addition to ILCP, discussed in Section 2, the Rosebud Sioux tribe has operated Tribal Land Enterprise, a land consolidation program, since 1943. This tribal land consolidation program has been able to consolidate 500,000 acres since its inception (National Congress of American Indians, 2011).

When comparing our Table 4 with Table 2.1 of the GAO report, two reservations stand out in terms of their change in tribal ownership. In 1992, the Blackfeet tribe was the sole owner of only 1,800 tracts. As of 2010, this figured increased to 5,367 tracts. The Crow tribe has also increased substantially their tribal land holdings, which in 2010 stands at 3,277 tracts, up from 823.

Individual Indians maintain outright ownership of 15,268 of the 98,269 tracts, or 15.5 percent, a decrease from the 20.7 percent of tracts owned solely by individual Indians in 1992.

The number of tracts with multiple owners, but at least one individual Indian owner, increased from 36,134 in 1992 to 43,770 in 2010, an addition of 7,636 tracts. This finding again shows the effect of fractionation on recordkeeping: the majority of these new tract records are not new acquisitions by individual Indians, but rather the result of single owned tracts splitting into multiple tract records, just as Tables 2 and 3 showed above. The number of tracts owned by a single individual Indian fell by 1,932 tracts, from 17,200 in 1992 to 15,268 in 2010 , an 11.2 percent decline.

Table 4: Ownership Profile of BIA-Managed Tracts

\begin{tabular}{|c|c|c|c|c|c|c|}
\hline \multirow[b]{2}{*}{ Reservation } & \multicolumn{3}{|c|}{ No. of tracts owned solely by } & \multicolumn{3}{|c|}{ No. of tracts with mulitple owners } \\
\hline & $\begin{array}{r}\text { One } \\
\text { Indian }\end{array}$ & Tribe & Others & $\begin{array}{l}\text { At least one } \\
\text { Indian owner }\end{array}$ & $\begin{array}{r}\text { No Indian } \\
\text { owners }\end{array}$ & $\begin{array}{l}\text { Total } \\
\text { tracts }\end{array}$ \\
\hline Blackfeet & 1,513 & 5,367 & 15 & 4,760 & 6 & 11,661 \\
\hline Cheyenne River & 1,994 & 6,231 & 65 & 3,899 & 17 & 12,206 \\
\hline Colville & 938 & 3,013 & 26 & 2,181 & 118 & 6,276 \\
\hline Crow & 1,815 & 3,277 & 23 & 4,753 & 9 & 9,877 \\
\hline Fort Berthold & 1,619 & 4,670 & 19 & 3,200 & 8 & 9,516 \\
\hline Fort Peck & 1,386 & 1,459 & 7 & 4,529 & 31 & 7,412 \\
\hline Pine Ridge & 2,296 & 3,552 & 72 & 5,863 & 52 & 11,835 \\
\hline Rosebud & 449 & 3,137 & 7 & 3,038 & 194 & 6,825 \\
\hline Standing Rock & 964 & 2,695 & 11 & 6,183 & 87 & 9,940 \\
\hline Turtle Mountain & 553 & 115 & 8 & 595 & 1 & 1,272 \\
\hline Wind River & 853 & 1,704 & 21 & 2,542 & 44 & 5,164 \\
\hline Yakama & 888 & 3,118 & 21 & 2,227 & 31 & 6,285 \\
\hline Total & 15,268 & 38,338 & 295 & 43,770 & 598 & 98,269 \\
\hline GAO 1992 & 17,200 & 29,134 & 253 & 36,134 & 257 & 82,978 \\
\hline
\end{tabular}

Note: this table corresponds to Table 2.1 in the 1992 GAO report.

\subsection{Ownership Mix on Tracts with Fractionated Ownership}

Table 5 provides summary statistics of the ownership mix for only those tracts with multiple owners and at least one individual Indian owner 7 The table shows the ownership composition of fractionated tracts has changed: in 1992 the majority of fractionated tracts were shared among individual Indians only. In 2010,

\footnotetext{
${ }^{7}$ This subset is the fifth column of Table 4 .
} 
Figure 3

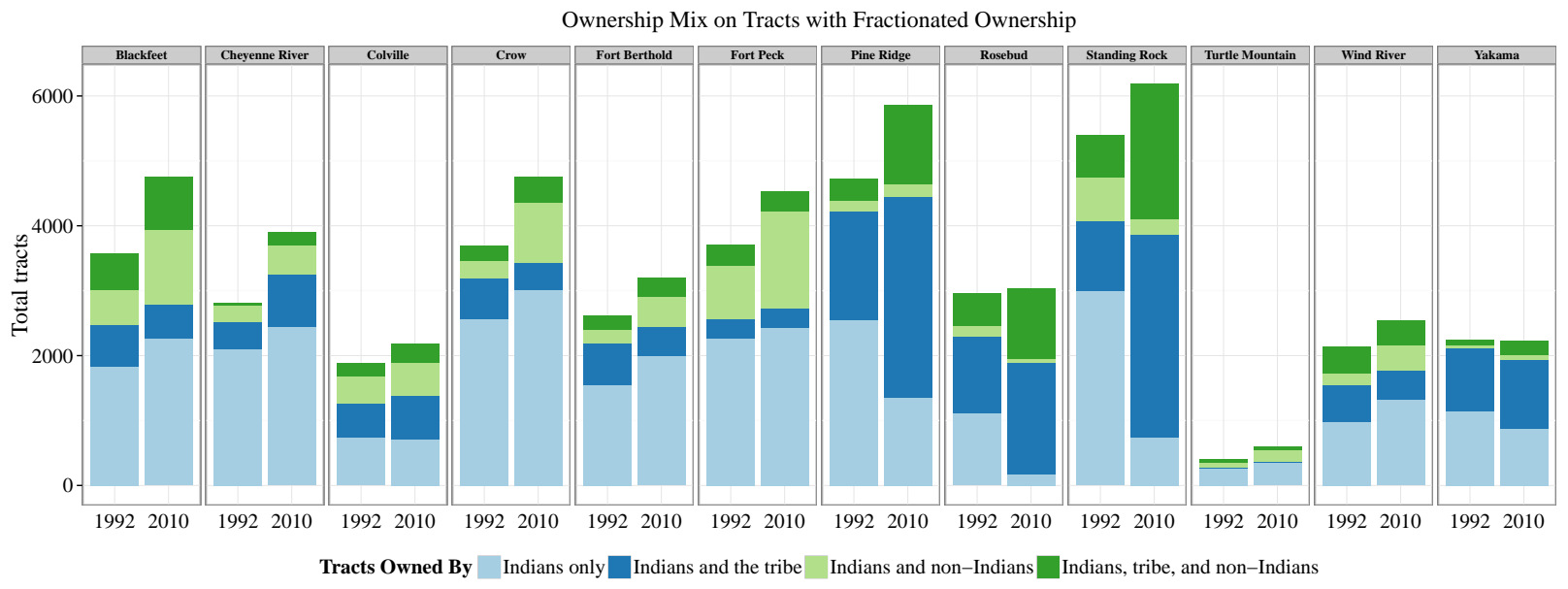

this category is still the largest owner subgroup, but the likelihood that ownership of a fractionated tract is now shared with a tribe, a non-Indian individual, or both, has increased considerably.

The number of fractionated tracts shared only by individual Indians, fell by 12 percentage points, from 20,084 to 17,682 . With the addition of the new tract records in the TAAMS data base, as discussed earlier, the share of fractionated tracts owned by Indians only, fell from 55.6 to 40 percent.

Table 5: Ownership Mix on Tracts with Fractionated Ownership

\begin{tabular}{lrrrrr}
\hline \multicolumn{5}{c}{ No. of tracts owned by } \\
\hline Reservation & $\begin{array}{r}\text { Indians } \\
\text { only }\end{array}$ & $\begin{array}{r}\text { Indians and } \\
\text { the tribe }\end{array}$ & $\begin{array}{r}\text { Indians and } \\
\text { non-Indians }\end{array}$ & $\begin{array}{r}\text { Indians, tribe, } \\
\text { and non-Indians }\end{array}$ & Total tracts \\
\hline Blackfeet & 2,268 & 518 & 1,153 & 821 & 4,760 \\
Cheyenne River & 2,451 & 798 & 449 & 201 & 3,899 \\
Colville & 704 & 671 & 518 & 288 & 2,181 \\
Crow & 3,021 & 407 & 935 & 390 & 4,753 \\
Fort Berthold & 1,997 & 454 & 452 & 297 & 3,200 \\
Fort Peck & 2,427 & 305 & 1,495 & 302 & 4,529 \\
Pine Ridge & 1,351 & 3,090 & 203 & 1,219 & 5,863 \\
Rosebud & 169 & 1,723 & 56 & 2,090 & 3,038 \\
Standing Rock & 737 & 3,127 & 240 & 46 & 6,183 \\
Turtle Mountain & 357 & 2 & 190 & 381 & 595 \\
Wind River & 1,329 & 439 & 393 & 212 & 2,542 \\
Yakama & 871 & 1,065 & 79 & 7,326 & 2,227 \\
Total & 17,682 & 12,599 & 6,163 & 3,596 & 43,770 \\
GAO 1992 & 20,084 & 8,652 & 3,802 & 36,134 \\
\hline
\end{tabular}

Note: this table corresponds to Table 2.2 in the 1992 GAO report.

As in Table 5, Figure 3 shows the ownership mix for fractionated tracts, while also comparing each reservation, between 1992 and 2010. From the figure we can see that the tribes on Pine Ridge, Rosebud, and Standing Rock have increased their tract holdings considerably since 1992. As mentioned above, the increase in Sioux tribal land holdings at Rosebud is likely due to their active land consolidation program. Both Standing Rock and Pine Ridge significantly participated in ILCP, so the increased tribal land holdings at these two reservations is likely caused by the combination of ILCP and the escheat provision of ILCA. 


\subsection{Tracts with Fractionated Ownership, by Number of Indian Owners per Tract}

Table 2.3 of GAO's report was surprising for two reasons. First, contrary to the anecdotal evidence of extreme cases of fractionation, cited in many Congressional hearings, tracts with more than 50 owners comprised only 9 percent of all 36,134 fractionated tracts in 1992. There were also only 26 tracts with 300 or more owners. About half of the fractionated tracts had 10 or fewer Indian owners. A second finding in that report is that the GAO provided almost no discussion of this table's results. Table 2.3 received only two sentences of explanation.

Like GAO's Table 2.3, our Table 6 groups the fractionated tracts by the number of Indian owners for 2010. Table 6 shows that 7,146 of the 43,770 fractionated tracts (i.e., 16.3 percent) contain over 50 separate ownership interests. In percentage terms the increase from 9 to 16.3 percent might seem small, but the total number of extremely fractionated tracts increased by more than double.

Table 6 contains a slight deviation from GAO's original Table 2.3. In order to include all of the 43,770 fractionated tracts, we add a column for fractionated tracts with a single individual Indian owner. Table 2.3 in the GAO report does not contain this column.

Breaking down fractionated tracts by the number of owners, Figure 4 highlights those tracts with high levels of fractionation. Between 1992 and 2010, the number of tracts with greater than 50 owners increased at all twelve reservations.

Table 6: Tracts with Fractionated Ownership, by Number of Indian Owners per Tract

\begin{tabular}{|c|c|c|c|c|c|c|c|c|c|}
\hline \multicolumn{10}{|c|}{ Number of tracts with } \\
\hline Reservation & $\begin{array}{r}\text { One } \\
\text { Indian } \\
\text { owner }\end{array}$ & $\begin{array}{r}\text { Two } \\
\text { Indian } \\
\text { owners }\end{array}$ & $\begin{array}{r}3-10 \\
\text { Indian } \\
\text { owners }\end{array}$ & $\begin{array}{r}11-25 \\
\text { Indian } \\
\text { owners }\end{array}$ & $\begin{array}{r}26-50 \\
\text { Indian } \\
\text { owners }\end{array}$ & $\begin{array}{c}51-100 \\
\text { Indian } \\
\text { owners }\end{array}$ & $\begin{array}{r}101-300 \\
\text { Indian } \\
\text { owners }\end{array}$ & $\begin{array}{r}\text { over } 300 \\
\text { Indian } \\
\text { owners }\end{array}$ & $\begin{array}{l}\text { Total } \\
\text { tracts }\end{array}$ \\
\hline Blackfeet & 82 & 355 & 1,179 & 1,181 & 787 & 759 & 408 & 9 & 4,760 \\
\hline Cheyenne River & 96 & 608 & 1,562 & 911 & 503 & 179 & 38 & 2 & 3,899 \\
\hline Colville & 343 & 252 & 740 & 426 & 259 & 112 & 49 & 0 & 2,181 \\
\hline Crow & 74 & 366 & 1,516 & 1,119 & 753 & 463 & 416 & 46 & 4,753 \\
\hline Fort Berthold & 54 & 319 & 1,137 & 755 & 423 & 318 & 179 & 15 & 3,200 \\
\hline Fort Peck & 149 & 461 & 1,491 & 1,132 & 698 & 421 & 164 & 13 & 4,529 \\
\hline Pine Ridge & 213 & 559 & 1,934 & 1,423 & 833 & 467 & 381 & 53 & 5,863 \\
\hline Rosebud & 237 & 239 & 942 & 711 & 441 & 246 & 206 & 16 & 3,038 \\
\hline Standing Rock & 295 & 376 & 1,859 & 1,650 & 947 & 673 & 326 & 57 & 6,183 \\
\hline Turtle Mountain & 8 & 119 & 175 & 125 & 58 & 41 & 55 & 14 & 595 \\
\hline Wind River & 37 & 161 & 599 & 552 & 462 & 360 & 307 & 64 & 2,542 \\
\hline Yakama & 81 & 205 & 723 & 543 & 386 & 212 & 77 & 0 & 2,227 \\
\hline Total & 1,669 & 4,020 & 13,857 & 10,528 & 6,550 & 4,251 & 2,606 & 289 & 43,770 \\
\hline GAO 1992 & & 4,757 & 13,553 & 9,628 & 4,944 & 2,391 & 835 & 26 & 36,134 \\
\hline
\end{tabular}

Note: this table corresponds to Table 2.3 in the 1992 GAO report.

\subsection{Largest Number of Owners on a Single Tract, by Reservation}

Table 6 summarized fractionation by ownership counts. An alternative way of studying fractionation is to analyze ownership percentage interests, instead of simply counting the number of owners. Table 7 provides this alternative analysis and the results are similar to those from Table 6.

The 1992 GAO report defines "small" ownership interest as one with a 1/50th interest (two percent), or less ${ }^{8}$ For each tract, Table 7 reports the counts of the number of ownership interests that are two percent

\footnotetext{
${ }^{8}$ GAO's designation of 2 percent as the cutoff for "small" ownership interests was due to the Indian Land Consolidation Act (ILCA) of 1983, which included an escheat provision for interests of two percent or less. As part of the original ILCA legislation, small interests would escheat to the tribe upon the death of an Indian with no will. This escheat provision ("Section 207") would be declared an unconstitutional taking, in Hodel v. Irving (1987), and an amended version of the provision was
} 
Figure 4

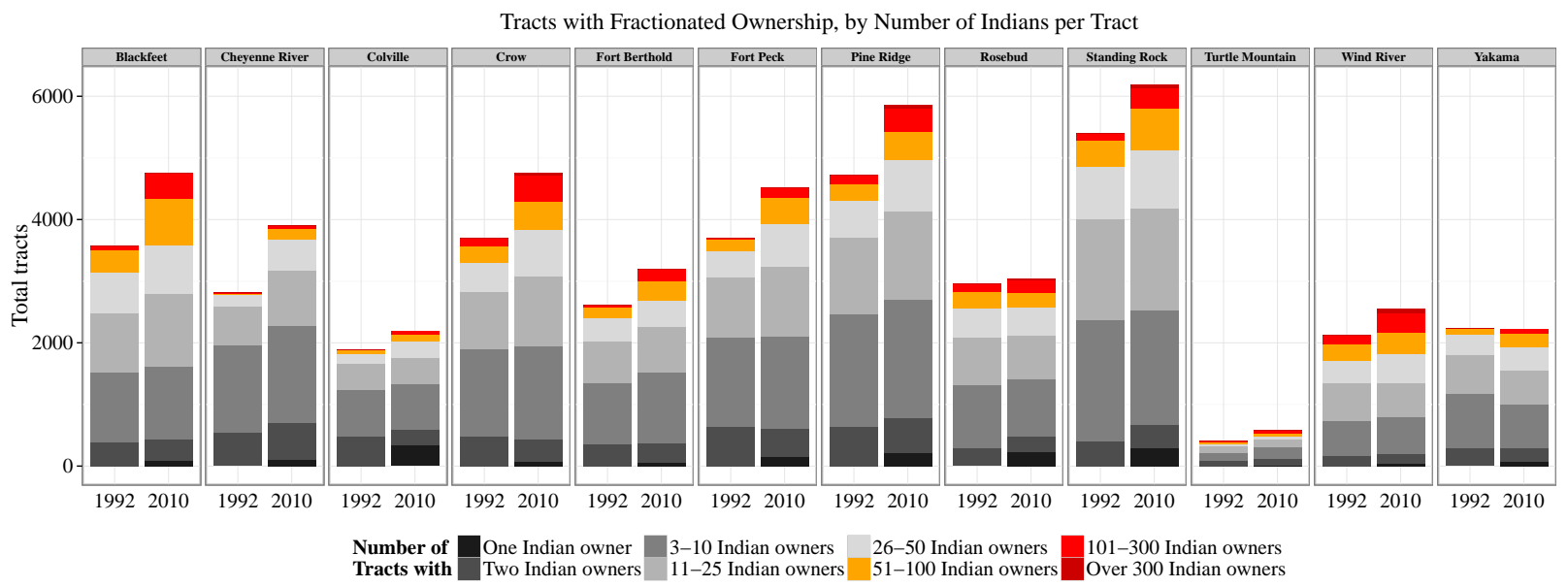

or less. Here again, we focus on the highly fractionated tracts.

Just as we showed in Table 6, above, the amount of highly fractionated tracts changed drastically by 2010. In 1992, only 6.2 percent $(2,243$ out of 36,134$)$ of the fractionated tracts contained more than 50 small ownership interests. Over half of the fractionated tracts contained no small interests. By 2010 the number of tracts with more than 50 small ownership interests more than doubled, increasing by 3,533 total tracts (Table 7). Tracts with no small ownership interests fell by only 110 tracts, to 19,174. By 2010 this category represented 43.8 percent of the fractionated tracts while it was 53.4 percent in 1992.

Table 7: Largest Number of Owners on a Single Tract, by Reservation

\begin{tabular}{|c|c|c|c|c|c|c|c|c|c|}
\hline \multicolumn{10}{|c|}{ Number of tracts with Indian interests of 2 percent or less } \\
\hline Reservation & None & One & $2-10$ & $11-25$ & $26-50$ & $51-100$ & $101-300$ & over 300 & Total \\
\hline Blackfeet & 1,844 & 18 & 767 & 645 & 569 & 577 & 333 & 7 & 4,760 \\
\hline Cheyenne River & 2,411 & 34 & 586 & 424 & 310 & 105 & 27 & 2 & 3,899 \\
\hline Colville & 1,309 & 22 & 302 & 251 & 173 & 83 & 41 & 0 & 2,181 \\
\hline Crow & 2,164 & 69 & 663 & 598 & 540 & 347 & 331 & 41 & 4,753 \\
\hline Fort Berthold & 1,636 & 29 & 522 & 307 & 309 & 240 & 142 & 15 & 3,200 \\
\hline Fort Peck & 2,279 & 42 & 682 & 643 & 443 & 292 & 138 & 10 & 4,529 \\
\hline Pine Ridge & 2,451 & 113 & 1,038 & 874 & 600 & 400 & 334 & 53 & 5,863 \\
\hline Rosebud & 886 & 93 & 754 & 513 & 348 & 234 & 195 & 15 & 3,038 \\
\hline Standing Rock & 2,124 & 136 & 1,236 & 1,089 & 703 & 555 & 287 & 53 & 6,183 \\
\hline Turtle Mountain & 317 & 6 & 78 & 58 & 34 & 38 & 50 & 14 & 595 \\
\hline Wind River & 809 & 31 & 387 & 372 & 320 & 287 & 277 & 59 & 2,542 \\
\hline Yakama & 944 & 34 & 439 & 329 & 287 & 132 & 62 & 0 & 2,227 \\
\hline Total & 19,174 & 627 & 7,454 & 6,103 & 4,636 & 3,290 & 2,217 & 269 & 43,770 \\
\hline GAO 1992 & 19,284 & 448 & 6,478 & 4,727 & 2,956 & 1,618 & 608 & 17 & 36,134 \\
\hline
\end{tabular}

Note: this table corresponds to Table 2.4 in the 1992 GAO report.

\subsection{Largest Number of Owners on a Single Tract, by Reservation}

To document the most highly fractionated tracts, Table 8 shows the most extreme example of fractionation at each reservation. Even with a Congressional focus on emphasizing the consolidation of small ownership interests, the ownership position of the most extreme examples of fractionation continued to increase at every single reservation.

ruled unconstitutional as part of Babbitt v. Youpee in 1997. Ultimately, the entire escheat provision was removed as part of amendments to ILCA that were passed by Congress in 2000. 
The number of total owners for these highly fractionated tracts ranged between 272 and 1,077 owners in 2010, up from 138 and 542, respectively, in 1992. The GAO reported that only one reservation, Standing Rock, contained a tract with as many as 500 different owners. By 2010, however, seven of the twelve reservations have at least one tract with over 500 owners.

In Table 8 we also report the total number of tribal affiliations represented. Because BIA included a tribal group code in our data, we can count the number of different tribes, whose members share ownership in the most extreme fractionized tract, for each reservation. As GAO reports, "Indian individuals can own interests in tracts on reservations that are not affiliated with their own tribes" (United States. General

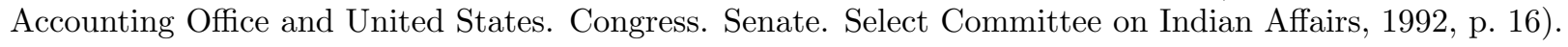

Table 8: Largest Number of Owners on a Single Tract, by Reservation

\begin{tabular}{lrrrrr}
\hline Reservation & $\begin{array}{r}\text { Indian } \\
\text { owners }\end{array}$ & $\begin{array}{r}\text { Other } \\
\text { owners }\end{array}$ & $\begin{array}{r}\text { Total } \\
\text { owners }\end{array}$ & $\begin{array}{r}\text { Indian } \\
\text { interests of } 2 \\
\text { percent or less }\end{array}$ & $\begin{array}{r}\text { Tribal } \\
\text { affiliations } \\
\text { represented }\end{array}$ \\
\hline Blackfeet & 442 & 56 & 498 & 441 & 8 \\
Cheyenne River & 459 & 20 & 479 & 442 & 16 \\
Colville & 259 & 19 & 278 & 244 & 10 \\
Crow & 696 & 6 & 702 & 678 & 10 \\
Fort Berthold & 456 & 21 & 477 & 448 & 17 \\
Fort Peck & 902 & 11 & 913 & 893 & 21 \\
Pine Ridge & 706 & 22 & 728 & 705 & 22 \\
Rosebud & 562 & 29 & 591 & 561 & 16 \\
Standing Rock & 1,053 & 24 & 1,077 & 1,050 & 25 \\
Turtle Mountain & 758 & 64 & 822 & 754 & 14 \\
Wind River & 937 & 7 & 944 & 927 & 23 \\
Yakama & 269 & 3 & 272 & 258 & 6 \\
\hline
\end{tabular}

Note: this table corresponds to Table 2.5 in the 1992 GAO report.

\subsection{Individual Indian Ownership in Multiple Tracts}

Just as a large number of ownership interests in a particular tract can cause problems for the economic use of the tract, so too can ownership interests in many tracts. It is hard enough to know the best use of a single resource. In addition, the knowledge required to effectively utilize land, increases with the number of tracts owned, especially if those tracts are geographically disparate. Thus, the likelihood of negative economic consequences due to fractionation is likely to increase as Indian ownership spreads across multiple tracts.

Table 9 breaks down the number of Indians who have ownership interests in one or more tracts. It shows that the number of individual Indians who own multiple tracts has increased, for all ownership categories, since 1992. Over 45 percent of the 116,838 individual Indian owners own interests in more than five tracts, up from 40 percent in 1992 9

\subsection{Indian with the Most Ownership Interests, by Reservation}

For each reservation, Table 10 shows the maximum number of ownership interests, the total number of tracts for those interests, and the number of two percent or less interests, owned by a single individual Indian. For example, on the Blackfeet Reservation, BIA maintains 213 separate ownership records for a single Indian

\footnotetext{
${ }^{9}$ The total number of owners, 116,838 , is not the number of unique Indian owners in the data. Because an Indian owner could own land in more than one reservation, some Indian owners are being double, or even triple, counted. The 79,710 owners reported by GAO also likely represents an inflated total, but GAO did not explicitly state this. In 2010 there were 87,020 unique owners. However, the 46.6 percent increase in total Indian owners shown here is similar in magnitude to the 46.1 percent increase in Indian reservation populations estimated in Table 1.
} 
Table 9: Individual Indian Ownership in Multiple Tracts

\begin{tabular}{|c|c|c|c|c|c|c|c|c|c|}
\hline \multicolumn{10}{|c|}{ Number of Indians with ownership in } \\
\hline Reservation & 1 tract & 2 tracts & $\begin{array}{r}3-5 \\
\text { tracts }\end{array}$ & $\begin{array}{r}6-10 \\
\text { tracts }\end{array}$ & $\begin{array}{c}11-25 \\
\text { tracts }\end{array}$ & $\begin{array}{r}26-50 \\
\text { tracts }\end{array}$ & $\begin{array}{r}51-100 \\
\text { tracts }\end{array}$ & $\begin{array}{r}\text { Over } 100 \\
\text { tracts }\end{array}$ & $\begin{array}{r}\text { Total } \\
\text { Indian } \\
\text { owners }\end{array}$ \\
\hline Blackfeet & 756 & 694 & 815 & 1,153 & 1,492 & 1,436 & 906 & 179 & 7,431 \\
\hline Cheyenne River & 1,285 & 1,023 & 1,730 & 1,590 & 1,693 & 346 & 39 & 1 & 7,707 \\
\hline Colville & 1,767 & 844 & 1,403 & 934 & 1,015 & 138 & 11 & 0 & 6,112 \\
\hline Crow & 769 & 319 & 678 & 353 & 855 & 646 & 759 & 486 & 4,865 \\
\hline Fort Berthold & 383 & 311 & 638 & 773 & 1,278 & 989 & 319 & 15 & 4,706 \\
\hline Fort Peck & 2,426 & 1,428 & 1,766 & 1,314 & 2,280 & 1,059 & 226 & 18 & 10,517 \\
\hline Pine Ridge & 4,596 & 3,099 & 4,215 & 3,751 & 4,641 & 1,270 & 180 & 6 & 21,758 \\
\hline Rosebud & 3,699 & 2,904 & 3,364 & 2,298 & 2,082 & 450 & 29 & 0 & 14,826 \\
\hline Standing Rock & 3,733 & 2,229 & 4,419 & 2,318 & 3,183 & 1,721 & 552 & 51 & 18,206 \\
\hline Turtle Mountain & 2,099 & 3,069 & 2,350 & 961 & 87 & 0 & 0 & 0 & 8,566 \\
\hline Wind River & 625 & 947 & 993 & 1,058 & 1,561 & 1,372 & 559 & 70 & 7,185 \\
\hline Yakama & 1,256 & 536 & 670 & 776 & 1,133 & 495 & 92 & 1 & 4,959 \\
\hline Total & 23,394 & 17,403 & 23,041 & 17,279 & 21,300 & 9,922 & 3,672 & 827 & 116,838 \\
\hline GAO 1992 & 20,101 & 11,304 & 15,767 & 11,958 & 13,920 & 5,340 & 1,189 & 131 & 79,710 \\
\hline
\end{tabular}

Note: this table corresponds to Table 2.6 in the 1992 GAO report.

owner. That Indian owns interests in 210 different tracts. Of that Indian's 213 interests, 157 of those (i.e., 74 percent) are an interest of two percent or less. Across all reservations, the number of tracts for which a single individual Indian had an ownership stake ranged between 2 and 241 in 1992. As of 2010, this figure ranged between 19 and 339. And for seven of the twelve reservations, ownership stakes of two percent or less made up the majority of the ownership interests. This shows that, even with a Congressional focus on consolidating small interests, the number of small interests owned by a single Indian increased on eleven of the twelve reservations.

Table 10: Indian with the Most Ownership Interests, by Reservation

\begin{tabular}{lrrr}
\hline Reservation & $\begin{array}{r}\text { No. of } \\
\text { tracts }\end{array}$ & $\begin{array}{r}\text { Ownership } \\
\text { interests }\end{array}$ & $\begin{array}{r}\text { Number of tracts } \\
\text { with ownership of } \\
2 \text { percent or less }\end{array}$ \\
\hline Blackfeet & 210 & 213 & 157 \\
Cheyenne River & 105 & 113 & 10 \\
Colville & 75 & 139 & 72 \\
Crow & 339 & 378 & 274 \\
Fort Berthold & 154 & 207 & 133 \\
Fort Peck & 156 & 166 & 73 \\
Pine Ridge & 137 & 142 & 112 \\
Rosebud & 77 & 125 & 76 \\
Standing Rock & 148 & 156 & 100 \\
Turtle Mountain & 19 & 40 & 1 \\
Wind River & 209 & 466 & 49 \\
Yakama & 104 & 150 & 159 \\
\hline
\end{tabular}

Note: this table corresponds to Table 2.7 in the 1992 GAO report.

\subsection{Individual Indians' Consolidated Ownership Interests, by Size of Interest}

One issue regarding the measurement of "fractionation" is that this term does not have a standard definition; it can be considered from many different levels. Thus, one could obtain vastly different images of fractionation depending on how the numbers are presented. For example, when the data is summarized in terms of owner counts or percentage interests per fractionated tract, such as in Tables 6 and 7, above, the 
fractionation picture might have initially appeared to be an isolated issue back in 1992. Using the same metrics, fractionation increased by 2010 , but it might still appear like a relatively small issue. Attesting to the various possible definitions of fractionation, the GAO presented the concept in several alternative ways. Table 11 groups the number of consolidated ownership interests by the size of the interest, just as GAO reported in their Table 2.8. With this approach, fractionation appears more prevalent then in the previous tables.

A large total number of interests on a tract give a misleading image of fractionation if those interests are all owned by a small number of individual Indians. For example, suppose two tracts both have 50 total ownership records. The degree of actual fractionation will be different for those tracts if the 50 interests are owned by just five Indians, rather than 50 separate owners. Thus, we actually want to look at both the total number of ownership interests, as above, as well as the number of consolidated interests-grouping multiple tract interests of a single owner into one record.

Aggregating all of these multiple small ownership claims, reduces the fractionation count, since it removes the duplication of owners. Even still, GAO reports that 61.2 percent of the consolidated interests amounted to a total interest of two percent or less. Applying the same procedure for 2010, shows that small interests represent over three-quarters of total consolidated interests $(1,009,138$ of $1,327,884)$.

For the change in the level of fractionation, between 1992 and 2010 the number of consolidated interests totaling two percent or less increased by 578,064 . This represents most of the increase in the total number of consolidated interests, 623,332. Further, the number of complete ownership interests, where a single individual Indian owned the complete tract, was 17,675 in 1992 (2.5 percent of total interests). This figure fell by 10.5 percent to 15,819 in 2010 (1.2 percent of total interests).

Table 11: Individual Indians' Consolidated Ownership Interests, by Size of Interest

\begin{tabular}{|c|c|c|c|c|c|c|c|}
\hline \multicolumn{8}{|c|}{ Number of consolidated ownership interests totaling } \\
\hline Reservation & $\begin{array}{r}100 \\
\text { percent }\end{array}$ & $\begin{array}{r}51-99.99 \\
\text { percent }\end{array}$ & $\begin{array}{r}26-50.99 \\
\text { percent }\end{array}$ & $\begin{array}{r}11-25.99 \\
\text { percent }\end{array}$ & $\begin{array}{r}>2-10.99 \\
\text { percent }\end{array}$ & $\begin{array}{r}2 \text { percent } \\
\text { or less }\end{array}$ & Total \\
\hline Blackfeet & 1,550 & 280 & 2,122 & 7,188 & 33,255 & 130,733 & 175,128 \\
\hline Cheyenne River & 2,081 & 176 & 2,466 & 6,727 & 18,166 & 33,454 & 63,070 \\
\hline Colville & 973 & 135 & 1,069 & 2,496 & 7,992 & 23,695 & 36,360 \\
\hline Crow & 1,896 & 333 & 2,426 & 8,091 & 28,350 & 129,023 & 170,119 \\
\hline Fort Berthold & 1,697 & 174 & 1,436 & 6,027 & 18,162 & 62,289 & 89,785 \\
\hline Fort Peck & 1,452 & 269 & 2,410 & 7,411 & 24,969 & 74,499 & 111,010 \\
\hline Pine Ridge & 2,325 & 268 & 2,502 & 7,017 & 24,360 & 147,914 & 184,386 \\
\hline Rosebud & 460 & 66 & 558 & 1,808 & 8,186 & 78,502 & 89,580 \\
\hline Standing Rock & 1,004 & 170 & 1,756 & 6,213 & 28,703 & 158,796 & 196,642 \\
\hline Turtle Mountain & 587 & 68 & 332 & 924 & 2,645 & 20,366 & 24,922 \\
\hline Wind River & 871 & 213 & 933 & 3,313 & 15,170 & 113,572 & 134,072 \\
\hline Yakama & 923 & 147 & 1,022 & 3,221 & 11,202 & 36,295 & 52,810 \\
\hline Total & 15,819 & 2,299 & 19,032 & 60,436 & 221,160 & $1,009,138$ & $1,327,884$ \\
\hline GAO 1992 & 17,675 & 4,108 & 20,714 & 59,987 & 171,004 & 431,074 & 704,562 \\
\hline
\end{tabular}

Note: this table corresponds to Table 2.8 in the 1992 GAO report.

Table 11 shows that small consolidated interests have increased by 578,064 . Highlighted in red, Figure 5 shows how those additional small interests break down by reservation.

\subsection{Smallest Indian Individual Ownership Interest, by Reservation}

Ownership interests for allotted tracts are for an "undivided" interest in the total acreage. This means that ownership interests do not refer to small physical sections of tract acreages, but rather the percentage interests of the total acreage. However, the 1992 GAO report illustrated examples of high levels of fractionation, by converting ownership interests into their land acreage equivalents, for the most extreme example at each 
Figure 5

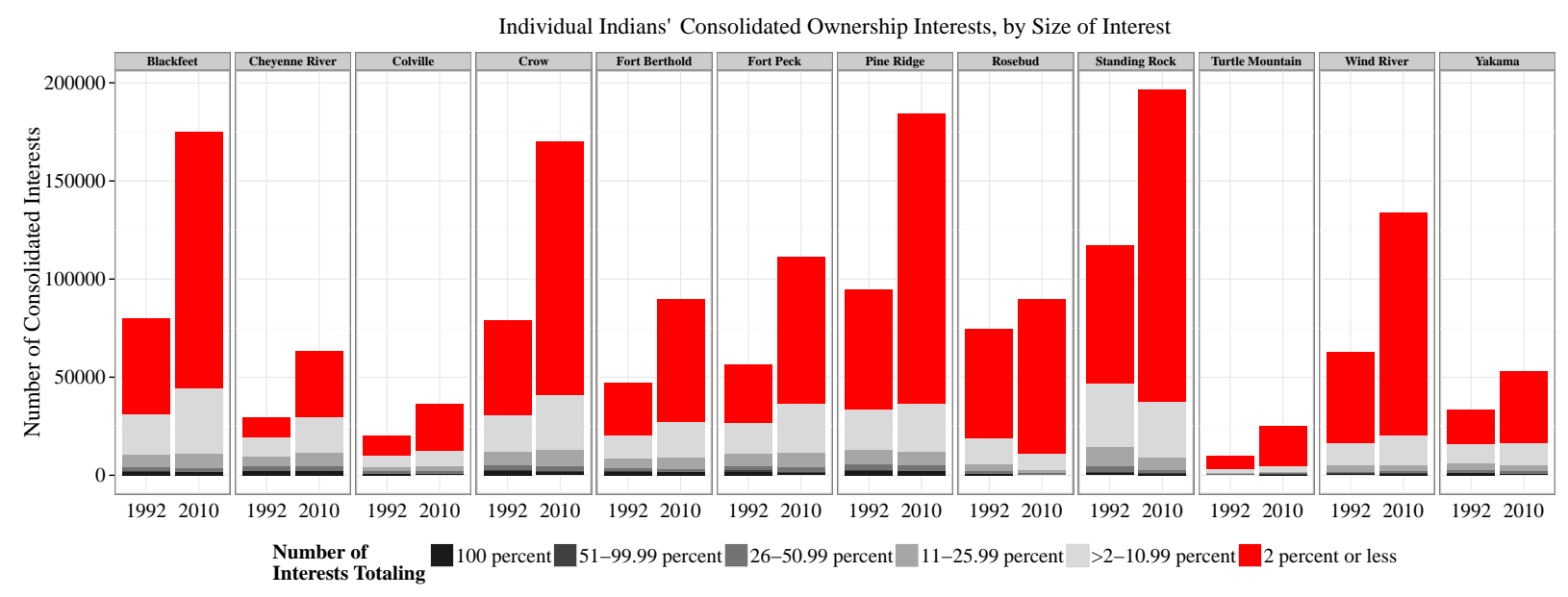

reservation. Table 12 shows that if the percentage ownership interests were converted to their land acreage equivalents, some Indians would own a section of land smaller than a postage stamp.

Table 12: Smallest Indian Individual Ownership Interest, by Reservation

\begin{tabular}{lrrrr}
\hline & & \multicolumn{2}{c}{ Land equivalent of ownership interest } \\
\hline Reservation & $\begin{array}{r}\text { Tract } \\
\text { acreage }\end{array}$ & $\begin{array}{r}\text { Percentage } \\
\text { ownership of } \\
\text { tract }\end{array}$ & $\begin{array}{r}\text { Square feet } \\
\text { Inches }\end{array}$ & \\
\hline Blackfeet & 80.00 & 0.000000059 & 0.21 & $5.5 \times 5.5$ \\
Cheyenne River & 160.00 & 0.000000482 & 3.36 & $22 \times 22$ \\
Colville & 160.00 & 0.000001518 & 10.58 & $39.03 \times$ \\
Crow & 160.00 & 0.000000005 & 0.04 & 39.03 \\
Fort Berthold & 80.00 & 0.000000103 & 0.36 & $7.2 \times 7.2$ \\
Fort Peck & 320.00 & 0.000000036 & 0.50 & $8.49 \times 8.49$ \\
Pine Ridge & 474.14 & 0.000000002 & 0.03 & $2.08 \times 2.08$ \\
Rosebud & 320.00 & 0.000000000 & 0.00 & $0 \times 0$ \\
Standing Rock & 320.00 & 0.000000000 & 0.00 & $0 \times 0$ \\
Turtle Mountain & 148.70 & 0.000000018 & 0.12 & $4.16 \times 4.16$ \\
Wind River & 80.00 & 0.000000003 & 0.01 & $1.2 \times 1.2$ \\
Yakama & 80.00 & 0.000000123 & 0.43 & $7.87 \times 7.87$ \\
\hline
\end{tabular}

Note: this table corresponds to Table 2.9 in the 1992 GAO report.

\subsection{Number of Ownership Records BIA Maintains}

In an effort to understand the BIA's recordkeeping workload, GAO reported the total number of (nonconsolidated) ownership records that BIA maintains. As of 1992, BIA was keeping track of over a million ownership records, for only these twelve reservations, using these records to "(1) identify land owners who must approve leasing and other land-use decisions, and (2) determine the distribution of lease and permit revenues" (GAO 1992, p. 21). Additionally, BIA maintains a running chronology of all the ownership status changes, which means that through TAAMS, BIA can recalculate the trust status of every tract dating back to the original allotments. As Table 13 shows, the number of non-consolidated records being maintained by BIA for these twelve reservations nearly doubled, from 1.06 to 2.1 million records in 2010. 
Table 13: Number of Ownership Records BIA Maintains

\begin{tabular}{lrrrr}
\hline \multicolumn{5}{c}{ Number of records maintained for tract ownership of } \\
\hline Reservation & $\begin{array}{r}\text { Surface } \\
\text { only }\end{array}$ & $\begin{array}{r}\text { Subsurface } \\
\text { only }\end{array}$ & $\begin{array}{r}\text { Both surface } \\
\text { and subsurface }\end{array}$ & $\begin{array}{r}\text { Total } \\
\text { ownership } \\
\text { records }\end{array}$ \\
\hline Blackfeet & 145,739 & 98,221 & 5,581 & 249,541 \\
Cheyenne River & 25,013 & 62,232 & 9,133 & 96,378 \\
Colville & 19,031 & 35,324 & 2,286 & 56,641 \\
Crow & 100,864 & 101,789 & 35,400 & 238,053 \\
Fort Berthold & 44,454 & 78,039 & 6,605 & 129,098 \\
Fort Peck & 26,360 & 76,688 & 45,679 & 148,727 \\
Pine Ridge & 69,319 & 101,673 & 141,955 & 312,947 \\
Rosebud & 47,611 & 85,032 & 81,238 & 213,881 \\
Standing Rock & 68,756 & 193,212 & 80,215 & 342,183 \\
Turtle Mountain & 12,724 & 14,761 & 8,750 & 36,235 \\
Wind River & 62,584 & 129,834 & 17,209 & 209,627 \\
Yakama & 925 & 12,191 & 64,411 & 77,527 \\
Total & 623,380 & 988,996 & 498,462 & $2,110,838$ \\
GAO 1992 & 234,134 & 397,524 & 427,934 & $1,059,592$ \\
\hline
\end{tabular}

Note: this table corresponds to Table 3.1 in the 1992 GAO report.

\subsection{Ownership Records, by Owner Type}

Table 14 groups the 2.1 million ownership records by owner type. As GAO reported,

According to BIA, it maintains ownership records for non-Indian individuals and others in certain situations, such as when Indians and others share tract ownership. BIA's practice is to maintain complete ownership records for all tracts that stem from an original land allotment as long as there continues to be an Indian ownership interest in the tracts (GAO 1992, p. 22).

Even as the total number of records nearly doubled, as we showed in Table 13, individual Indians accounted for fewer of these ownership records, in percentage terms, than they did in 1992. Individual Indians owned 90 percent of total records in 1992, and 84 percent in 2010 (1,771,953 of 2,110,991). Table 14 also shows tribal ownership records trebled, over the same period. Again, the reduction in individual ownership and the increase in tribal ownership is likely the result of the escheat provision of ILCA and BIA's Indian Land Consolidation program. This increase in tribal ownership records matches the results of Table 4 , where it showed that the number of tracts owned solely by tribes increased by a third.

\subsection{Individual Indian Ownership Records, by Size of Ownership Interest}

Table 15 groups the 1.7 million individual Indian ownership records by the size of the interest. Similar to the results presented in Table 11, interests of two percent or less comprised about sixty-six percent of all individual Indian ownership records in 1992, and comprised eighty percent of the total in 2010. GAO's Table 4.1 reports that two percent interests account for only forty-nine percent of all Indian ownership records in 1983, prior to Congress passing ILCA.

Another approach to analyze fractionation is to study the rate increase of small interests. As GAO reported in 1992, the number of interests of two percent or less doubled during the interval between 1983 and GAO's study, where 1983 marked the passage of ILCA and its escheat provision. In 1992 the total number of small ownership interests had increased by 315,000, from 305,000 in 1983 to 620,511 (United States. General Accounting Office and United States. Congress. Senate. Select Committee on Indian 
Table 14: Ownership Records, by Owner Type

\begin{tabular}{lrrrrr}
\hline \multicolumn{7}{c}{ Number of ownership records } & \\
\hline Reservation & $\begin{array}{r}\text { Tribal } \\
\text { interests }\end{array}$ & $\begin{array}{r}\text { Individual } \\
\text { Indians }\end{array}$ & $\begin{array}{r}\text { Non- } \\
\text { Indians }\end{array}$ & Other & $\begin{array}{r}\text { Total } \\
\text { ownership } \\
\text { records }\end{array}$ \\
\hline Blackfeet & 9,607 & 233,150 & 6,769 & 12 & 249,538 \\
Cheyenne River & 11,822 & 83,521 & 1,035 & 0 & 96,378 \\
Colville & 6,506 & 48,042 & 2,090 & 3 & 56,641 \\
Crow & 9,176 & 226,152 & 2,704 & 20 & 238,052 \\
Fort Berthold & 7,902 & 120,210 & 1,165 & 3 & 129,280 \\
Fort Peck & 2,664 & 142,268 & 3,761 & 13 & 148,706 \\
Pine Ridge & 67,243 & 242,639 & 3,023 & 42 & 312,947 \\
Rosebud & 96,549 & 114,417 & 2,915 & 0 & 213,881 \\
Standing Rock & 82,991 & 254,071 & 5,117 & 4 & 342,183 \\
Turtle Mountain & 189 & 34,434 & 1,612 & 0 & 36,235 \\
Wind River & 3,849 & 203,561 & 2,154 & 59 & 209,623 \\
Yakama & 7,529 & 69,488 & 495 & 15 & 77,527 \\
Total & 306,027 & $1,771,953$ & 32,840 & 171 & $2,110,991$ \\
GAO 1992 & 94,328 & 948,160 & 13,923 & 3,271 & $1,059,682$ \\
\hline
\end{tabular}

Note: this table corresponds to Table 3.2 in the 1992 GAO report.

Affairs, 1992, p. 2) ${ }^{10}$ This increase translates into an average of 35,000 new small interests per year over that nine-year period. We find that between 1992 and 2010, the total number of small interests grew by 802,164 (from 620,511 to $1,422,675$ ). The average rate of new small interest creation has accelerated to 44,500 per year.

\subsection{Profile of Individual Indian Owners}

Table 16 reports the break down between tribe members and non-member Indians. Table 16 shows that an Indian owner in 2010 is more likely to be a tribal member than in 1992. Owners with tribal membership increased ten percentage points between 1992 and 2010, up to 98 percent of total Indian owners.

Additionally, as GAO calculated, BIA was maintaining an average of between 11 and 12 records per individual Indian. For 2010, we calculate this figure has increased to over 15 records per individual Indian owner (1,771,953 total records from Table 15 divided by the number of individual Indians from Table 16, $116,838) 11$

The GAO study did include one final table related to ILCA (1983). They reported the number of tracts that had escheated to the tribes as of May 1991. Unfortunately, we lack the data to provide an update to that final table.

\footnotetext{
${ }^{10}$ In the GAO report it is not immediately obvious where this calculation comes from, so we outline it explicitly here. The GAO is comparing figures from their Table 4.1 (United States. General Accounting Office and United States. Congress. Senate. Select Committee on Indian Affairs 1992 p. 26) and Table 3.3 (United States. General Accounting Office and United States. Congress. Senate. Select Committee on Indian Affairs 1992 p. 23). In Table 4.1 GAO lists the number of two percent interests prior to the passage of ILCA in 1983 at 305,392 and at 620,511 for 1992 in Table 3.3.

${ }^{11}$ Both the GAO figure and our calculation from the 2010 data understate reality. As we discussed in footnote 10 , the totals used in these calculations are not the number of unique individual Indian owners. The number of unique owners is much smaller, due to some double counting across reservations, which decreases the actual records per Indian we report. We preserved the GAO method to maintain consistency.
} 
Table 15: Individual Indian Ownership Records, by Size of Ownership Interest

\begin{tabular}{|c|c|c|c|c|c|c|c|}
\hline \multicolumn{8}{|c|}{ Number of records with percentage ownership interest of } \\
\hline Reservation & 100 & 51-99.99 & $26-50.99$ & $11-25.99$ & $>2-10.99$ & 2 or less & $\begin{array}{r}\text { Total Indian } \\
\text { records }\end{array}$ \\
\hline Blackfeet & 1,413 & 185 & 2,065 & 7,741 & 36,634 & 185,112 & 233,150 \\
\hline Cheyenne River & 2,035 & 90 & 2,454 & 7,125 & 21,324 & 50,493 & 83,521 \\
\hline Colville & 854 & 98 & 1,206 & 2,732 & 9,330 & 33,822 & 48,042 \\
\hline Crow & 1,749 & 313 & 2,662 & 8,514 & 32,741 & 180,173 & 226,152 \\
\hline Fort Berthold & 1,602 & 130 & 1,544 & 6,099 & 19,990 & 90,845 & 120,210 \\
\hline Fort Peck & 1,432 & 207 & 2,370 & 7,918 & 27,673 & 102,668 & 142,268 \\
\hline Pine Ridge & 2,098 & 156 & 2,550 & 7,836 & 27,615 & 202,384 & 242,639 \\
\hline Rosebud & 422 & 34 & 552 & 1,918 & 9,300 & 102,191 & 114,417 \\
\hline Standing Rock & 913 & 77 & 1,625 & 6,448 & 31,448 & 213,560 & 254,071 \\
\hline Turtle Mountain & 559 & 52 & 358 & 1,148 & 3,320 & 28,997 & 34,434 \\
\hline Wind River & 785 & 160 & 952 & 3,290 & 16,903 & 181,471 & 203,561 \\
\hline Yakama & 800 & 170 & 1,082 & 3,282 & 13,195 & 50,959 & 69,488 \\
\hline Total & 14,662 & 1,672 & 19,420 & 64,051 & 249,473 & $1,422,675$ & $1,771,953$ \\
\hline GAO 1992 & 16,477 & 2,125 & 21,119 & 63,540 & 203,263 & 620,511 & 927,035 \\
\hline
\end{tabular}

Note: this table corresponds to Table 3.3 in the 1992 GAO report.

Table 16: Profile of Individual Indian Owners

\begin{tabular}{lrrr}
\hline \multicolumn{3}{c}{ Indian Owners } \\
\hline Reservation & Non-members & Members & Total \\
\hline Blackfeet & 186 & 7,245 & 7,431 \\
Cheyenne River & 168 & 7,539 & 7,707 \\
Colville & 76 & 6,036 & 6,112 \\
Crow & 67 & 4,798 & 4,865 \\
Fort Berthold & 59 & 4,647 & 4,706 \\
Fort Peck & 213 & 10,304 & 10,517 \\
Pine Ridge & 478 & 21,280 & 21,758 \\
Rosebud & 320 & 14,506 & 14,826 \\
Standing Rock & 463 & 17,743 & 18,206 \\
Turtle Mountain & 118 & 8,448 & 8,566 \\
Wind River & 141 & 7,044 & 7,185 \\
Yakama & 100 & 4,859 & 4,959 \\
Total & 2,389 & 114,449 & 116,838 \\
GAO 1992 & 9,787 & 70,074 & 79,861 \\
\hline
\end{tabular}

Note: this table corresponds to Table 3.4 in the 1992 GAO report. 


\section{Implications and Conclusions}

Our review of the BIA data shows that fractionation is continuing its growth path, regardless of which measure is being used. Total ownership records managed by BIA for these twelve reservations have doubled and consolidated interests have nearly doubled, having risen by 94 percent. The average rate at which new small interests are being added to the TAAMS system has increased from 35,000 per year from 1983 to 1992 to 44,500 per year from 1992 to 2010. The number of tracts that have over 50 owners has also more than doubled.

In light of these facts, the sum of all Congressional activity, in the 82 years since the release of the Meriam Report, has been unsuccessful at stopping fractionation. Thus far, no legislative remedy has proved to be the solution for fractionation in Indian country.

However, we can also evaluate specific actions by Congress and BIA. Starting with the "Section 207" of ILCA-which allowed for the escheatment of land interests to the tribes-we can use a counterfactual approach to estimate the effectiveness of this escheatment provision.

As GAO reports in Table 4.1, 16,404 interests escheated to tribes between 1983 and 1992, or approximately 1,823 interests per year. Since we now know about the growth of fractionation between 1992 and 2010, we can estimate how many pieces those 16,404 interests would have broken into, absent Section 207 of ILCA. Between 1992 and 2010 the number of interests of two percent or less increased by 130 percent. If we apply the same rate of increase to those 16,404 escheated interests, we estimate there would have been around 37,729 more interests of two percent or less in 2010.

However, we also know that more such escheatments occurred after 1992, until the two percent rule was again ruled unconstitutional in Babbitt v. Youpee (1997). The DOI reports that a total of 55,000 interests escheated to tribes under Section 207 (United States. Department of the Interior, 2000). These 55,000 escheatments represent the total for all reservation land areas. As documented in Table 15, our twelve reservation sample contains 1.4 million small interests. That total represents 63 percent of the roughly 2.2 million small interests across all reservations in 2010. Assuming that Section 207 impacted each reservation equally, then approximately 63 percent of the 55,000 escheatments would be expected to have happened at the twelve reservation subset. Thus, we have to add 18,246 escheatments to the previous total of 16,404. If we assume escheatment occurred evenly between 1992 and 1997, then 3,649 escheatments occurred per year. Applying a similar growth path calculation to these escheatments results in an estimated reduction of 34,661 small interests in 2010. Adding those reductions to our previous estimate brings the total reduction of small interests to 72,271 .

The total number of two (or less) percent ownership interests at the twelve reservations is 1,422,675 for 2010 (Table 15). Thus, our calculation suggests that absent Section 207, small interests would be 4.8 percent higher in 2010. Since an average of over 44,500 new small interests are being created each year, Section 207 eliminated less than two years' worth of small interest growth.

Section 207 triggered two Supreme Court cases, Hodel v. Irving (1987) and Babbitt v. Youpee (1997), and many legislative sessions to amend Section 207 between 1983 and 2000. In hindsight, if the litigation costs of the two court cases and the costs of those legislative sessions are compared to the modest reduction of small ownership interests, then our calculation suggests that Section 207 costs exceeded its benefits even if it had been constitutional. As we explain below, the alternative policy of voluntary land consolidation programs has the potential to be more effective at achieving the goal of land consolidation, as opposed to than Section 207 and without any constitutional concerns.

Addressing concerns regarding BIA's recordkeeping costs, Congress requested GAO to estimate the total cost of records maintenance as part of their detailed accounting of fractionation. At the time, a BIA official estimated the cost to be between $\$ 40$ and $\$ 50$ a year, per record. Putting the yearly cost of ownership records maintenance for the twelve reservations at between $\$ 40$ and $\$ 50$ million 12 GAO estimated that $\$ 24$

\footnotetext{
${ }^{12} \mathrm{GAO}$ also noted that this figure should serve as a lower bound estimate because it "does not include the cost of the judicial process associated with resolving the inheritance of allotted land" (United States. General Accounting Office and United States. Congress. Senate. Select Committee on Indian Affairs, 1992 , p. 25).
} 
to $\$ 31$ million of this total went to servicing the interests of two percent or less. In 1998 DOI estimated that 50 to 75 percent ( $\$ 33$ million) of its realty budget was dedicated to the administration of small ownership interests (Cohen, 1998).

A comparable per record cost figure for 2010 is not available. However, the Indian Land Tenure Foundation (ILTF) "estimated in 2005 that the annual administrative cost to the federal government was $\$ 120$ per undivided interest. A subsequent estimate by the BIA staff put the number slightly higher at $\$ 125$ per interest per year" (Indian Land Tenure Foundation, 2011). With the increased number of records maintained by BIA at these twelve reservations, and using BIA's $\$ 125$ cost estimate, we estimate the cost of maintaining the 2.11 million records for the 12 reservation subset to be $\$ 264$ million annually. Table 14 shows that total records are increasing at an average rate of 58,406 new records per year. Thus, we estimate the total cost of recordkeeping at these twelve reservations grows by over $\$ 7$ million per year. In 2010 there are 4.6 million ownership records maintained by BIA for the entire trust land base, which puts BIA's total recordkeeping costs at $\$ 575$ million annually.

Many of the records being tracked by BIA are so small that the actual value of the interests might be worth only a few dollars or even a few pennies over the lifetime of the interest holder. Regardless of how small the interests get, or how much income those interests earn, BIA is required to account for that income. Accordingly, the recordkeeping cost figures suggest that BIA could actually save money by paying a price for these interests that exceed their actual value for these extremely small interests and thereby simply closing out those records.

A similar conclusion was offered by Deputy Solicitor Cohen who testified before Congress that the average dollar value of a small ownership interest was estimated to be $\$ 200$ in GAO's 1992 study. Mr. Cohen went on to say these interests would "cost BIA between $\$ 1,500$ and $\$ 2,000$ to probate the landowner's estate," (Cohen, 1998) and that this cost did not vary with the value of the land contained therein. The BIA is charged with administering these estates regardless of their dollar value. Thus, Mr. Cohen concluded, "while we can implement new systems to minimize some costs, the labor intensive processes of probating estates and obtaining owner consents on leases or sales will continue. Savings from the cost of probating an Indian estate alone justifies the cost of acquiring fractional interests" (Cohen, 1998). For example, under ILCP, BIA estimates that land consolidation avoided as many as 5,536 potential probate cases. At $\$ 1,500$ to $\$ 2,000$ per case, ILCP helped BIA avoid between $\$ 8$ and $\$ 11$ million in probate expenses (Chickasaw Nation Industries, 2012).

Since BIA continues to spend a large amount of resources simply administering small ownership interests, an "aggressive" strategy of acquiring and consolidating fractional interests could save the federal government a considerable amount of money. A complete elimination of fractionation, and the associated recordkeeping, would save upwards of six billion dollars in recordkeeping costs alone, over the next ten years.

How "aggressive" would a land consolidation strategy have to be to have a significant impact on fractionation?

In Section 2 we discussed a land consolidation program, the ILCP, which the BIA has operated since 1999. Through 2010 ILCP has spent $\$ 174.9$ million, purchasing 401,300 fractional interests, covering 639,330 acres, across twenty different reservations (Chickasaw Nation Industries, 2012) ${ }^{13}$ In his 2004 testimony, Trustee Swimmer pointed to this program as being "successful" and foreshadowed the program's expansion from 2005 to 2009. However, our data shed some doubt on its level of success. We showed that in 2010, BIA managed 8 million surface acres and 5.8 million subsurface acres belonging to fractionated tracts. Assuming the purchased interests refer to surface area acres only this program took eleven years to reduce fractionated surface areas by only eight percent.

Even though land consolidation programs have shown modest returns to date, land consolidation programs still maintain the potential to be the solution for fractionation. The figures presented above suggest

\footnotetext{
${ }^{13}$ The twenty reservations are, for BIA's Great Plains Region, Rosebud, Standing Rock, Pine Ridge, Winnebago, and Sisseton. For the Midwest Region, Bad River, Lac Courte Oreilles, Lac du Flambeau, Red Cliff, Keweebaw Bay, Grand Portage, Boise Forte, and Ho Chunk. In the Northwest Region, Quinault, and the Confederated Salish and Kootenai. The four remaining reservations are Eastern Navajo (Navajo Region), Gila River (Western), Crow (Rocky Mountain), and Quapaw (Eastern Oklahoma).
} 
that land consolidation is going to require a larger scale and scope. In terms of scale, in 2003 the Director of BIA's Western Region, Wayne Nordwall, testified before the Senate Committee on Indian Affairs and cited an Office of Management and Budget estimate that a national land consolidation program would require around $\$ 2$ billion to completely eliminate fractionation (Nordwall, 2003). That estimate is now over a decade old but it puts the current challenge into perspective. Allocating $\$ 2$ billion to consolidate fractionated land is an expensive federal outlay, but if we have correctly estimated the potential $\$ 6$ billion in savings from the elimination of BIA recordkeeping, then a national land consolidation program represents an investment with a positive return for both taxpayers and Indian land owners.

The recently settled Cobell v. Salazar case, discussed in Section 2, presents the prospect of generating net benefits from such an investment opportunity. A national land consolidation program was included in the class action settlement signed by President Obama in December of 2012. The $\$ 3.4$ billion settlement allocates $\$ 1.9$ billion to be spent by the ILCP to purchase fractionated interests on Indian trust land over the next decade (United States. Department of the Interior, 2012). ${ }^{14}$ And $\$ 1.9$ billion is close to the amount that the Office of Management and Budget estimated with respect to the financial requirements for a successful national program .

For the Cobell land consolidation program to achieve its potential, it is likely that the federal government will also have to increase the scope of this program. Currently the ILCP is authorized to purchase interests only from willing sellers. A voluntary only purchase program is problematic for completely ending fractionation because BIA must be able to purchase tracts in their entirety. Leaving even a single interest will allow for continued fractionation and require further costly recordkeeping by BIA. It is frequently the case that Indian owners cannot be located, or simply do not respond to purchase announcements.

Consequently, if the ILCP is to be effective at eliminating fractionation, Congress and BIA must authorize some scope for compulsory purchases by ILCP. A full discussion on the feasibility of using federal eminent domain authority on Indian reservations would require the exposition of issues in federal Indian law that are beyond the scope of this study. However, as part of the amendments to ILCA in 2000, tribes already have a power similar to eminent domain. If the tribe maintains a controlling interest in a tract, greater than 50 percent, then tribes "have the authority to direct the sale of land" (National Congress of American Indians, 2011). A concerted effort by BIA to increase the role of tribal involvement in the operation of the ILCP could increase that program's effectiveness. Since it is likely that the future path of fractionation in Indian country depends on the successful implementation of this Cobell settlement land consolidation program, the strategy with the best chance for success might be one where BIA coordinates their purchases with the eminent domain authority of tribes.

\section{Technical Appendix}

This document was created using $\mathrm{R}$ version 3.0.1 and the $\mathrm{R}$ package knitr (Xie, 2013). It also relied on the $\mathrm{R}$ packages data.table (Dowle et al. 2013), extrafont (Chang, 2013), extrafontdb (Chang, 2012), ggplot2 (Wickham and Chang, 2013), Hmisc (Harrell, 2013), plyr (Wickham, 2012a), repmis (Gandrud, 2013), reshape2 (Wickham, 2012b), and stringr (Wickham, 2012c).

\footnotetext{
${ }^{14}$ The remaining $\$ 1.5$ billion is to be dispersed directly to Indian land owners through their IIM accounts within the BIA.
} 


\section{References}

Akee, R. (2009). Checkerboards and coase: The effect of property institutions on efficiency in housing markets. Journal of Law and Economics, 52(2):395-410.

Anderson, T. L. and Lueck, D. (1992). Land tenure and agricultural productivity on indian reservations. Journal of Law and Economics, 35(2):427-454.

Anderson, T. L. and Parker, D. P. (2006). The wealth of indian nations: Economic performance and institutions on reservations. Self-Determination: The Other Path for Native Americans, 159.

Babbitt v. Youpee (1997). 519 u.s. 234, 117 s. ct. 727, 136 l. ed. 2d 696.

Bobroff, K. H. (2001). Retelling allotment: Indian property rights and the myth of common ownership. Vand. L. Rev., 54:1557.

Carlson, L. (1981). Indians, bureaucrats, and land: the Dawes act and the decline of Indian farming. Contributions in economics and economic history. Greenwood Press.

Chang, W. (2012). extrafontdb: Package for holding the database for the extrafont package. R package version 1.0.

Chang, W. (2013). extrafont: Tools for using fonts. R package version 0.15 .

Chickasaw Nation Industries (2012). Indian land consolidation project experience.

Cobell v. Salazar (1987). 573 f.3d 808, 130 s. ct. 3497; 177 l. ed. 2d 1085.

Cohen, E. B. (1998). Testimony before the house committee on resources concerning h.r. 2743, to reduce fractionated ownership of indian lands and for other purposes, hearing, july 29, 1998. federal document clearing house congressional testimony.

Demsetz, H. (1967). Toward a theory of property rights. The American economic review, 57(2):347-359.

Di Giulio, J. A. (1994). For the benefit of indian peoples: An analysis of indian land consolidation policy.

Dowle, M., Short, T., with contributions from A Srinivasan, S. L., and Saporta, R. (2013). data.table: Extension of data.frame for fast indexing, fast ordered joins, fast assignment, fast grouping and list columns. $\mathrm{R}$ package version 1.8.10.

Gandrud, C. (2013). repmis: A collection of miscellaneous tools for reproducible research with $R$. $\mathrm{R}$ package version 0.2.6.2.

Gilbert, W. H. and Taylor, J. L. (1966). Indian land questions. Ariz. L. Rev., 8:102.

Guzman, K. R. (2000). Give or take an acre: Property norms and the indian land consolidation act. Iowa Law Review, 85(2):595-662.

Harrell, Jr., F. E. (2013). Hmisc: Harrell Miscellaneous. R package version 3.12-2.

Heller, M. A. (1998). The tragedy of the anticommons: property in the transition from marx to markets. Harvard law review, pages 621-688.

Hodel v. Irving (1987). 481 u.s. 704, 107 s. ct. 2076, 95 l. ed. 2d 668.

Indian Land Tenure Foundation (2011). Amicus curiae brief by the indian land tenure foundation in support of plaintiffs-appellees and defendants-appellees.

Indian Land Tenure Foundation (2012). Fractionated ownership.

Lindo, M. M. (1997). Youpee v. babbitt: The indian land inheritance problem revisited. American Indian Law Review, 22(1):223-246. 
McChesney, F. S. (1990). Government as definer of property rights: Indian lands, ethnic externalities, and bureaucratic budgets. The Journal of Legal Studies, 19(2):297-335.

McCulley, K. L. (2005). The american indian probate reform act of 2004: The death of fractionation or individual native american property interests and tribal customs? American Indian Law Review, $30(2): 401-422$.

Meriam, L. et al. (1928). The problem of indian administration. report of a survey made at the request of honorable hubert work, secretary of the interior, and submitted to him, february 21, 1928.

National Congress of American Indians (2011). Draft talking points on 1.9 billion for land consolidation of fractionated lands.

Nordwall, W. (2003). Statement to senate committee for indian affairs, hearing, may 7, 2003. federal document clearing house congressional testimony.

Reis, P. (2009). Obama admin strikes $\$ 3.4 \mathrm{~b}$ deal in indian trust lawsuit. New York Times.

Shoemaker, J. A. (2003). Like snow in the spring time: Allotment, fractionation, and the indian land tenure problem. Wis. L. Rev., page 729 .

Swimmer, R. O. (2004). Testimony before the committee on resources hearing on s.1721, the american indian probate reform act of 2004, hearing, june 23, 2004. federal document clearing house congressional testimony.

United States. Department of the Interior (2000). Summary of trust management problems, need for action and special trustees strategic plan recommendations. Technical report.

United States. Department of the Interior (2012). Initial implementation plan: Land buy-back program for tribal nations. Technical report.

United States. General Accounting Office and United States. Congress. Senate. Select Committee on Indian Affairs (1992). Indian programs: profile of land ownership at 12 reservations: briefing report to the Chairman, Select Committee on Indian Affairs, US Senate. The Office.

Wickham, H. (2012a). plyr: Tools for splitting, applying and combining data. R package version 1.8.

Wickham, H. (2012b). reshape2: Flexibly reshape data: a reboot of the reshape package. R package version 1.2 .2 .

Wickham, H. (2012c). stringr: Make it easier to work with strings. R package version 0.6.2.

Wickham, H. and Chang, W. (2013). ggplot2: An implementation of the Grammar of Graphics. R package version 0.9.3.1.

Xie, Y. (2013). knitr: A general-purpose package for dynamic report generation in $R$. R package version 1.5. 